\title{
Impact of Metallic Nanoparticles on Anaerobic Digestion: a Systematic Review
}

\author{
Xaowen Zhu ${ }^{\mathrm{a}}$, Edgar Blanco ${ }^{\mathrm{b}}$, Manni Bhatti ${ }^{\mathrm{a}}$, Aiduan Borrion ${ }^{* a}$ \\ ${ }^{a}$ Department of Civil, Environmental and Geomatic Engineering, University College London, UK. \\ ${ }^{\mathrm{b}}$ Anaero Technology Limited, Cowley Road, Cambridge, UK. \\ *corresponding author: A.Borrion@ucl.ac.uk
}

\section{Abstract}

Anaerobic digestion (AD) is one of the most energy-efficient waste treatment technologies for biodegradable wastes. Owing to the increasing trend of metallic nanoparticle applications in industry, they are ubiquitous to the waste streams, which may lead to remarkable impacts on the performance of the AD process. This review addresses the knowledge gaps and summarises the findings from the academic articles published from 2010 to 2019 focusing on the influences on both AD processes of biochemical hydrogen-generation and methaneproduction from selected metallic nano-materials. Both qualitative and quantitative analyses were conducted with selected indicators to evaluate the metallic nanoparticles' influences on the AD process. The selected metallic nanoparticles were grouped in the view of their chemical formulations aiming to point out the possible mechanisms behind their effects on AD processes. In summary, most metallic nanoparticles with trace-elementbase (e.g. iron, cobalt, nickel) have positive effects on both AD hydrogen-generation and methane-production processes in terms of gas production, effluent quality, as well as process optimisation. Within an optimum concentration, they serve as key nutrients providers, aid key enzymes and co-enzymes synthesis, and thus stimulate anaerobic microorganism activities. As for the nano-additives without trace-element base, their positive influences are relied on providing active sites for the microorganism, as well as absorbing inhibitory factors. Moreover, comparisons of these nano-additives' impacts on the two gas-production phases were conducted, while methane-production phases are found to be more sensitive to additions of these nanoparticles then hydrogen-production phase. Research perspectives and research gaps in this area are discussed.

Keywords: Anaerobic digestion, metallic additives, nano-additives, nanoparticles

\section{Introduction}

Anaerobic digestion (AD) is a complex anoxic biochemical process that converts biomass or organic waste into biogas and nutrient-rich digestate. The nutrient-rich digestate product is also known as effluent. Based on the main metabolic groups of microorganisms involved, the AD process can be divided into four stages: hydrolysis, fermentation or acidogensis, acetogenesis, and methanogenesis (Fig. 1) (Arif et al., 2018). Considering its 
energy input and recovery, as well as impacts on the environment, $\mathrm{AD}$ is one of the most cost-effective applications among all the biodegradable waste disposal technologies (Khalid et al., 2011; Sawatdeenarunat et al., 2015; Zhen et al., 2017).

Direct (Fig.1A) and indirect (Fig.1B) inhibition factors affect both the stability and efficiency of AD processes, which may consequently lead to failure of the AD process (Fagbohungbe et al., 2017). Moreover, though liquid digestate from anaerobic digesters can be used as liquid fertiliser, which provides essential nutrients for plant growth and maintaining soil ecosystem (Montemurro et al., 2010; Qin et al., 2015), it may also cause leaching of the nitrogen and volatilisation of large amounts of ammonia (over $85 \%$ of the ammonium inside the effluent becomes ammonia through direct land application) (Rehl and Müller, 2011), owing to the fast release of this nutrient by diffusion (Fagbohungbe et al., 2017). This type of liquid fertiliser also causes the release of pathogens and heavy metals (Demirel et al., 2013; Fagbohungbe et al., 2017). Whilst the gas state output (biogas) always requires post-treatment to remove impurities, such as hydrogen sulphide (Seadi et al., 2008). Previous studies (Fagbohungbe et al., 2017; Osuna et al., 1997) have reported that the applications of some additives, such as micro-nutrients (MNs) and nano-materials could optimise the AD process by absorbing inhibitory factors and pathogens, thus enhance biogas production and effluent quality.

The additions of metallic micro-nutrients, especially trace elements and their composites could effectively enhance AD performance (Osuna et al., 1997). Since MNs provide essential constituents for enzymes and coenzymes, it can stimulate microbial bioactivity and microbial growth rate (Mao et al., 2015; Osuna et al., 1997; Qiang et al., 2013). Recent studies have shown that the supplementations of nano-additives cause more obvious impacts on digesters in relation to biogas yield and methane content than those in micrometric size under the same dosage condition (Juntupally et al., 2017). Due to larger surface area to volume ratio, better specificity, more capable of self-assembly, and dispensability, this type of nano-scaled additive exhibited higher reactivity in comparison with MNs (Abdelsalam et al., 2017a).

On the other hand, as a type of ultrafine materials, nanoparticles are not easy to be separated from biodegradable wastes, which may subsequently cause accumulation of inorganic pollutants (usually heavy metals) inside anaerobic digesters. The heavy metals are non-biodegradable, as a result, the AD process cannot effectively remove them from feedstock (Chipasa, 2003). Most of the escaped inorganic pollutants from treatment plants are directly disposed through land applications or released into the water cycle, threatening the aquatic ecosystem and human health (Ni et al., 2019). In addition, due to the toxicity of heavy metals to microorganisms, even low concentrations of metals can inhibit the AD process (Karvelas et al., 2003; Lee et al., 2018; Zayed and Winter, 2000).

Application of metallic nano-additives can be either dosed at a single point in one-stage AD systems together with feedstock or dosed twice in two-stage $\mathrm{AD}$ systems in which the first dosage at the beginning for $\mathrm{AD}$ acidogensis phase, whilst the second dosage after $\mathrm{AD}$ fermentation for the methane production process. The additions of some nano-additives, such as nano-scaled iron and its oxides, induce remarkable enhancements 
under both of the abovementioned scenarios at very low concentrations (approximately $10 \mathrm{mg} / \mathrm{L}$ ), stimulating activities of microorganisms and key enzymes (Lei et al., 2018; Zaidi et al., 2018; Zhang et al., 2018), therefore leading to more gas production, as well as better effluent quality. In fact, most of the nano-additives are capable to absorb inhibitory compounds including heavy metals, and trap these compounds on their surface (Lei et al., 2018; J. Zhang et al., 2019).

To date, there are no systematic reviews regarding metallic nanoparticles and their impacts on the whole $\mathrm{AD}$ process, which can be further separated into the fermentation stage and methane-production phase. Moreover, no reviews in this area took both effluent quality and process optimisation into account. Considering the increasing attention towards organic waste streams, and the significant effects of nanoparticles (NPs) on biochemical processes, this review aims to summarise the findings of academic articles published between 2010 to 2019 on applications of metallic nano-materials in the AD process. Meanwhile, the objective of this review is to provide insights to the influences released by selected metallic nanoparticles on the AD process in terms of gas yield (bio-hydrogen from fermentation phase, methane, carbon dioxide, and hydrogen sulphide for the overall $\mathrm{AD}$ process), effluent quality, as well as their influences on fundamental mechanisms, such as $\mathrm{pH}$, chemical oxygen demand (COD), volatile fatty acids (VFAs) production and oxygen-reduction potential (ORP). Finally, the research gaps in this area have been reviewed, and the suggested perspectives have been listed.

\section{Approach}

In this study, academic publications related to impacts on anaerobic digestion from metallic nanoparticles released between January 2010 and October 2019 were included. The literature search was conducted with English as searching language in October 2019 using Google Scholar and Science Direct.

Fig. 2 summarised the process of literature search and research framework of this review. The search keywords were set according to the types of metallic nanoparticles and research interests on different AD phases. While the types of metallic nanoparticles included in this study were first categorized based on their chemical components, followed by classification of the research interests on different phases of AD processes. Over 1000 papers were retrieved with the searching keywords. A refined search with modified keywords to remove irrelevant publications was then conducted. Afterwards, the titles and abstracts of all the searched publications were manually screened, which duplicates, repeated and irrelevant publications were removed. In the end, full texts of the remaining publications were reviewed to match the inclusive criteria, and targeted searches were carried out to ensure covering all the publications in this area.

\subsection{Classification of metallic nanoparticles}


102 The types of metal nanoparticles conducted in this review were selected based on the list of nano-materials

103 either currently used for commercial or being produced in significant quantities for research or developmental 104 purposes (Lovestam et al., 2010). The categories of the nanoparticles were first selected based on their chemical 105 components, then further classified by their known impacts on microorganisms as 'trace-element-based' and 106 'non-trace-element-based'. For example, both nano zero-valent iron (nano-Fe ${ }^{0}$ ) and nano spinel ferrite (nano$107 \mathrm{AFe}_{2} \mathrm{O}_{4}$, where $\mathrm{A}$ stands for metals, such as cobalt and zinc) were categorised under 'iron-based' nano-additives, 108 and grouped into 'trace-element-based' nanoparticles together with zinc-based nano-additives subsequently. In 109 total twenty-three types of metallic nanomaterials are covered in this review, the detailed categories, as well as their abbreviations used in the following sections are presented in Table S.1.

\subsection{Search strategy}

113 Applications of metallic nanoparticles could be either in one-stage or two-stage AD systems with fermentation 114 and methane-production phase (Bharathiraja et al., 2016; Ding et al., 2010; Hallenbeck, 2009). The research 115 interests of impacts from metallic nano-materials on the AD process mainly focused on the AD fermentation 116 and methane-production process. In this case, the methane-production process might either refer to the overall 117 AD process for a one-stage AD system, or the methane-production phase in a two-stage AD system. Thereby, 118 the initial search keywords for this review were set as a combination of three terms: anaerobic digestion, 119 research interests on $\mathrm{AD}$ phases, together with types of metallic nanoparticles. For example, the following 120 search strategy was used to identify academic publications till the end of 2019 about the zinc-based nano121 materials influences on the AD fermentation phase:

Search keywords in title and abstract of academic papers: ("anaerobic digestion") AND ("fermentation" OR "hydrogen production" OR "bio-hydrogen”) AND ("nano zinc”).

122 The second search term related to research interests was set to "methane" OR "biogas" when searching publications focused on in the methane-production process. All the search results were narrowed to academic publications written in English, whilst a large number of publications about iron-based nanoparticles were found irrelevant with the attraction of this review. With refined search keywords for iron-based nanoparticles, the third search term about types of nano-material was changed to "nano" AND "zero-valent iron" OR "ferric" OR "magnetite" OR "spinel ferrite" OR "iron oxide". While the third search term of aluminium-oxide nanoparticles was updated to "nano" AND "alumina". Duplicates were then removed (89 publications), and 151 publications were excluded from this review after manually screening their abstracts. These were publications mainly focused on the fate of nanoparticles inside anaerobic digesters, or tested with unknown source of feedstock and inoculum, or experiments ran without temperature control. In this stage, the following inclusive criteria were used to screen the full text of the remaining 94 publications: 
1. Full text is available, with at least methodology section, as well as primary or secondary data;

2. At least the impacts on the volume of harvested gas were mentioned, with either the roles of nanomaterials in $\mathrm{AD}$ processes, or influences on effluent quality referred to as supplementary information in the publications;

3. The exact sizes of nanoparticles applied in its corresponding research were stated, and within the range listed in the following criteria;

4. Considering the narrow size range of the nanoparticles (1-100nm), and limitations in synthesis and storage of them, this review includes results from publications with the size of additives below 400nm.

After removing repeated publications, a total of 67 research articles were identified that matched the criteria and were saved for further data extraction eventually. In addition, 4 publications were manually added into this systemic review by targeted search, which were cited by the existing selected publications.

\subsection{Data extraction procedure}

Both qualitative and quantitative analysis of this review were developed based on the data extraction from the selected publications. The main outcomes of the analysis and summary tables of data extraction are presented in the Section of Results and Discussion. For each publication, the following information was recorded for further analysis:

1. Publications year;

2. Characteristics of applied nano-materials, including their chemical forms and sizes;

3. Reported concentrations of the nano-material dosage, that have remarkable influences on the AD process, either they were positive or negative;

4. Operation conditions of the AD systems, including types of substrates and inoculum, temperature, as well as operation time;

5. Main results.

More specifically, data extracted from the main results of each selected paper for structured analysis were summarised into three key themes to modify the metallic nano-materials effects on AD systems. The key themes including impacts on gas production and effluent quality, as well as nano-materials roles on the AD process. Based on the studies by Bajpai et al. (2017) and Alvarado et al. (2014), in total 29 indicators were selected to evaluate the impacts from these metallic nano-additives on the key themes, with more details presented in Table S.2.

\subsection{Limitations}


165 This review contained several unavoidable limitations during search and results from synthesis processes, 166 though these processes were designed to be as comprehensive as possible. One of the main limitations of this 167 review is that it only includes publications written in English. Moreover, since the choice of concentration units 168 of nano-materials additions and indicators to modify the AD process, as well as the selection of feedstock and 169 inoculum, vary between publications. Therefore, direct comparisons cannot be made, which means the results 170 of this paper cannot be used to sum up the entire research area. Finally, as the publications without stating exact 171 sizes of the applied nano-materials, the results from these publications were excluded from the analysis of this 172 review.

\section{Results and Discussion}

\subsection{Categorisation of the Content}

178 Fig. 3 shows the counts of publications of metallic nanoparticles interested in this review with categories based 179 on their chemical formations. The most studied nano-material is nano- $\mathrm{ZnO}$ (in total 17 publications), followed 180 by nano zero-valent iron and nano- $\mathrm{Fe}_{3} \mathrm{O}_{4}$ (both had 15 publications). While at the sub-category level, in total 44 181 publications researched the group of iron-based nanoparticles, 16 publications tested zinc-based nanoparticles, 182 and 8 publications studied titanium-based nanoparticles, respectively. Several sub-categories of metallic nano183 materials, such as molybdenum- and manganese-based nano-materials only got 1 publication in the past 10 184 years. Among the selected 71 publications, over half of them (52\%) evaluated the impacts from at least two 185 types of nanomaterials, whilst 4 of them focusing on AD systems amended by multi-nano-additives. It should 186 be mentioned that only Fig. 3 was constructed based on all the selected publications. Whilst the other quantity 187 analyses conducted in this section were developed with separated research interests, with terms "methane188 production process" covered both the overall AD process in a single-stage AD system, and methane-production 189 phases in a two-stage AD system.

\subsubsection{Operation Conditions}

192 Anaerobic digesters can be used to treat all the biodegradable wastes, and transform them into biogas and liquid 193 effluent under three different temperature conditions (ambient, mesophilic and thermophilic) (Arif et al., 2018). 194 Among all the included studies, most experiments (64\% for AD fermentation phase, 91\% for methane195 production and overall AD processes) were conducted under mesophilic conditions (Fig. S.1).

Apart from operation temperature, the selection of feedstock (e.g. choice of substrate and inoculum, a combination of substrate and inoculum, as well as substrate to inoculum ratio) was recognised as another 
198 important factor that may lead to varying in influences on AD amended with the same metallic nano-material.

199 Six combinations of substrate and inoculum have been implemented by researchers studying metallic nano200 materials impacts on the $\mathrm{AD}$ fermentation phase. Among these selections, the combination of growth medium 201 and single strain hydrogen-producing bacteria (over 30\%), such as Clostridium and Enterobacter, was the most 202 commonly used feedstock, followed by the combination of growth medium and mixed culture bacteria from 203 wastewater treatment plants (over 20\%) (Fig. S.2). Moreover, anaerobic sludge applied for the tests on AD 204 fermentation was usually amended with a heat pre-treatment for the enrichment of hydrogen-producing bacteria 205 (Gadhe et al., 2015).

206 As for the studies focused on methane-production processes, in total 33 combinations of feedstock and inoculum 207 were implemented by the researchers. Whilst 21 types of feedstock only contain one publication for each type, 208 and thus categorised in a group of 'Other' in Fig. S.2. Among these feedstocks, the combination of model growth 209 medium and anaerobic granular sludge (over 10\%) was the most popular feedstock, followed by pure animal 210 manure (10\%), pure waste activated sludge (7.3\%) and combination of animal manure and effluent from 211 anaerobic digesters (7.3\%).

212 Comparing with the studies on the $\mathrm{AD}$ fermentation phase, it is rare to see the research interested in methane213 production processes applying single strain methane-producing bacteria and growth medium. Instead, half of 214 the experiments used substrate from wastewater treatment plants, and effluent or sludge from anaerobic 215 digesters as inoculum. Furthermore, the components of the growth medium were slightly different from the 216 abovementioned growth medium prepared for $\mathrm{AD}$ fermentation phase, which contained selected individual 217 VFAs, such as acetic acids (Gonzalez-Estrella et al., 2013).

\subsubsection{Studies on influences on AD process and research trends}

220 There is an increasing trend in the number of publications studied metallic nanoparticles influences on the 221 performance of AD systems since 2010, with a major peak in 2015 (Fig. S.3). Over $80 \%$ of the studies (59 out 222 of 71) selected in this review focuses on the methane-production phase and the overall AD processes, while the remaining 12 articles focus on the metallic nanoparticle effects on $\mathrm{AD}$ fermentation phase.

A range of indicators was used to identify and qualify the impacts on AD systems from metallic nano-materials for both research interests (Fig. S.4). A total number of 9 indicators were implemented for the performance of the $\mathrm{AD}$ fermentation phase, whereas 23 indicators were applied for the performance of methane-production processes. In terms of quality of outputs, most studies measured the volume of gas production, including biohydrogen yield (67\% for studies interested in AD fermentation phase) and bio-methane yield (74\% for studies

229 focused on the methane-production process). On the other hand, researches tend to focus more on effluent 230 quality from the $\mathrm{AD}$ fermentation phase than it on methane-production and overall $\mathrm{AD}$ processes. 
231 Interestingly, $67 \%$ of the studies interested in the $\mathrm{AD}$ fermentation phase measured final total or individual 232 VFAs concentrations for effluent quality. In contrast, the chemical oxygen demand removal rate is the most 233 studied indicator for effluent quality of the methane-production process, but it was only used in $11.8 \%$ of the 234 total number of publications. In addition, for both research interests, most indicators ( 7 out of 9 for AD 235 fermentation phase, 13 out of 23 for methane-production process) were included to measure influences on $\mathrm{AD}$ 236 process.

237 In the following sub-sections, the impacts on AD processes from metallic nanoparticles are summarised and 238 discussed based on the research interests (AD fermentation phase, as well as methane-production and overall 239 AD processes). Furthermore, a separate sub-section for the co-additives system was summarised (see sub240 section 3.5 for more details) in which four articles mentioned the additions of multi-metallic-nanoparticles are 241 reviewed.

\section{$244 \quad 3.2 \quad$ Influences on AD Fermentation Phase}

245 Owing to variances in the dominant microbial communities and the responsible enzymes of these two research 246 interests, the influences from the same metallic nanoparticles on the AD fermentation phase, as well as the 247 methane-production and overall AD processes may be different. The bio-hydrogen produced from the AD 248 fermentation phase is catalysed by hydrolysis-acidification microorganisms via a redox reaction of proton 249 transfer (Bharathiraja et al., 2016; Ding et al., 2010; Hallenbeck, 2009), which is immediately used by 250 methanogens to form methane in the one-stage AD system. Whilst in the two-stage AD system, the harvested 251 bio-hydrogen can either be used directly as a clean energy source or combined with carbon dioxide to form 252 methane (Dong et al., 2019). Furthermore, the effluent from this process can also be used as feedstock for 253 methane generation for a two-stage AD system (Bharathiraja et al., 2016). Through the AD fermentation phase, 254 enzymes, such as $\mathrm{Fe}$-hydrogenase and Ni-hydrogenase, also play important roles apart from bacteria in 255 stabilising pH and optimising metallic nutrients (Bharathiraja et al., 2016; Sakinah et al., 2017).

256 Based on the results from quantitative analysis (Fig. 4), among all the tested metallic nano-materials, only nano$257 \mathrm{Cu}$ was reported to have antagonistic effects on the fermentation stage with all the dosage concentrations 258 (Mohanraj et al., 2016). All the other nano-materials were found to have positive impacts on the utilisation of intermediates (i.e. dissolved biomass after hydrolysis) and final VFA production. Of notice, Hsieh et al., (2016) 260 have reported nano-hematite (nano- $\gamma-\mathrm{Fe}_{2} \mathrm{O}_{3}$ ) slightly hindered the substrate to hydrogen conversion process with 261 dosage over $100 \mathrm{mg} / \mathrm{L}$.

262 The following Table 1 listed the highest reported concentrations of selected metallic nanoparticles that either 263 lead to the best performance of the AD fermentation phase, or no adverse effects on bio-hydrogen production 
under mesophilic condition. Whilst the concentrations for "the best performances of AD fermentation phase" means beyond this concentration, the positive impacts on this phase decline or vanish.

Among all the metallic nano-additives, the ones with iron-base presented the highest reported tolerant concentrations to over $150 \mathrm{mg} / \mathrm{L}$. Meanwhile, low concentrations of both nano-ZnO and $\mathrm{NiO}$ enhanced the AD fermentation phases slightly without adverse impacts, and the appearance of nano-copper inhibited the AD fermentation phase completely. More details were summarised and discussed in the following sub-sections and Supplementary Documents (see Supplementary Table S.3).

\subsubsection{Trace-element-based nano-additives}

\section{- Iron-based nanoparticles}

Published results in the past ten years on AD fermentation from three types of iron-based nanoparticles were assessed, including $\alpha-\mathrm{Fe}_{2} \mathrm{O}_{3}, \gamma-\mathrm{Fe}_{2} \mathrm{O}_{3}$, and iron oxide nanoparticles (IONPs). In terms of output quality (i.e. the volume of harvested gas, final total or individual VFA production) and process stability, all the iron-based nanoadditives have positive impacts on the performance of $\mathrm{AD}$ fermentation. The maximum increase in the volume of bio-hydrogen of $153.3 \%$ was reported by amended growth medium and treated anaerobic sludge with $50 \mathrm{mg} / \mathrm{L}$ IONPs $(6.5 \pm 3 \mathrm{~nm})$. The iron-based nanoparticles play important roles in the enhancement of bio-hydrogen production, because they can release iron cations $\left(\mathrm{Fe}^{2+}\right)$ to synthesis and stimulate key enzymes, and facilitate electron transfer between the enzymes ferredoxin oxidoreductase and hydrogenase (Hsieh et al., 2016). Furthermore, the enhancement in bio-hydrogen production normally occurs in accordance with increased concentrations of acetate, butyrate, and release of protons through their metabolic pathways (Mohanraj and Kodhaiyolii, 2014). In addition, increased concentration of acetate and butyrate which are known as energy favourable volatile fatty acids (VFAs) for the methane production phase(Wang et al., 2018a), may consequently promote the AD process.

Several factors may affect the influences on $\mathrm{AD}$ fermentation phase by iron-based nanoparticles, including types of iron-based nano-additives, $\mathrm{pH}$, as well as the nanoparticles exposure concentrations. As an exception among all the iron-based nanoparticles, the bio-hydrogen generated from feedstock amended by nano zero-valent iron (nZVI) was found largely corresponded with its dissolution into water under anaerobic conditions (as shown in Eq.1) (Huang et al., 2016).

$$
\mathrm{Fe}^{0}+2 \mathrm{H}_{2} \mathrm{O} \rightarrow \mathrm{Fe}^{2+}+\mathrm{H}_{2}+2 \mathrm{OH}^{-}
$$

As for IONPs, 2 out of 3 studies agreed that the samples amended by them presented a better performance in measurements of final bio-hydrogen production when compared to the ones treated with Iron sulphite $\left(\mathrm{FeSO}_{4}\right)$. Though both forms of iron can facilitate the activities of ferredoxin, thus accelerate the release of protons via the metabolism of pyruvate, only the groups fed with IONPs shifted the main fermentation pathway from 
297 butyrate to acetate/butyrate with higher glucose utilisation efficiency (Mohanraj et al., 2014; Mohanraj and 298 Kodhaiyolii, 2014).

299 Within the optimum range of $\mathrm{pH}$ for the $\mathrm{AD}$ fermentation phase from 4 to 10 , the decrease in $\mathrm{pH}$ results in an 300 increase in the number of ferric cations $\left(\mathrm{Fe}^{2+}\right)$ released from iron-based nanoparticles and form more 301 bioavailable iron compounds for dominant microorganism communities (Han et al., 2011).

302 Moreover, the amount of recovered bio-hydrogen was found to linearly correlate with the amount of iron-based nanoparticles added below tolerant concentrations $(\leq 200 \mathrm{mg} / \mathrm{L})$ (Gadhe et al., 2015). If the dosage of iron-based nanoparticles increases beyond this upper limit (dosage of $1600 \mathrm{mg} / \mathrm{L}$ ), the reactors still achieved a shorter lag period, but reduced hydrogen contents and overall volumes of the generated gas (Han et al., 2011). Meanwhile, more ethanol and propionate were yielded, but less acetate and butyrate were produced from the digesters amended with a higher concentration. The possible mechanism behind these observations is the release of iron cations, which can stimulate the activities of hydrogen-production bacteria under optimum concentration. However, the presence of iron cations is a double-edged sword that the excessive amount of iron cations beyond the tolerant concentration of the AD bacteria might cause bacterial cell lysis and prevent the process (Han et al., 2011).

\section{- Zinc-based nanoparticles}

313 In the case of only one publication was found for zinc-based nanoparticles influences focusing on AD bio314 hydrogen production, several studies mentioned this nanoparticle's impacts on AD hydrolysis and acidogensis 315 phase were also included in the discussion. In summary, the addition of low concentrations (10 mg/g VS) of 316 nano-ZnO exhibited positive influences on bio-hydrogen production (Elreedy et al., 2019). The growth in gas 317 production may attribute to the involvement of zinc-dependent enzyme ADH, which can catalyse the conversion 318 between alcohols and aldehydes (Eq. 2) (Elreedy et al., 2019). Regarding the number of microbial copies, the 319 dosage of nano-ZnO enriched the relative abundance of key hydrogen producer Clostridiales. At the meantime, Thermoanaerobacterales was inhibited, which is known as a group of bacteria that use ADH enzymes to produce ethanol from acetaldehyde. In parallel, a decline in the concentration of acetaldehyde and a rise in acetic acid concentration was observed after an incubation time of 48 hours. This provides substantial evidence of the system utilizing acetaldehyde to produce its corresponding carboxylic acid and protons $\left(\mathrm{H}^{+}\right)$Eq.3 (Trifunović et al., 2016).

In terms of the reported highest dosed concentrations, the $\mathrm{AD}$ fermentative bacteria are less tolerant of the zincbased nanoparticles in comparison to the iron-based nanoparticles. This is associated with the antibacterial activities causing by zinc ions $\left(\mathrm{Zn}^{2+}\right)$ that are released from corrosion and dissolution of zinc nanoparticles. $\mathrm{Mu}$ et al. (2012), who studied the influences from nano-ZnO addition to anaerobic granular sludge (AGS), found 
that once the dosage went beyond $50 \mathrm{mg} / \mathrm{g}$ TSS, the nano-ZnO prevented the generation of all the functional groups in extracellular polymeric substances (EPS) except polysaccharide contents. The EPS normally functions as a shield protecting the microorganisms from environmental pollutants. Nonetheless, if the addition of nano$\mathrm{ZnO}$ kept raising to over $100 \mathrm{mg} / \mathrm{g}$ TSS, the concentration of $\mathrm{Zn}^{2+}$ ions surpassed the chemical adsorption capacity of EPS, which means the EPS no longer trap the cations of released from nano-ZnO and leading to further reduction in EPS production (Mu et al., 2012).

\section{- Nickel-based nanoparticles}

Similar to the abovementioned zinc-based nanoparticles, all the studies interested in the impacts from nickelbased nanoparticles on the AD fermentation phase focused on the form of nickel oxide (nano-NiO). All the selected publications agreed that the addition of nano-NiO at low concentrations ( 5 and $10 \mathrm{mg} / \mathrm{g} \mathrm{VS}$ ) have great improvements (over 15\%) on the bio-hydrogen production (Elreedy et al., 2019; Gadhe et al., 2015; Sakinah et al., 2017). Nano-NiO serves as a source of $\mathrm{Ni}^{2+}$ for several metal-enzymes including [Fe-Ni] hydrogenase and acetyl-CoA synthetase (ACS) (Boer et al., 2014). Hydrogenase catalyses bio-hydrogen production and ACS helps to convert acetyl-CoA to acetate, thus the addition of nano-NiO facilitates the conversion of acetaldehyde to acetyl-CoA (Trifunović et al., 2016).

However, inhibition in $\mathrm{AD}$ fermentation system under mesophilic conditions were reported with nano-NiO at a dosage of only $10 \mathrm{mg} / \mathrm{L}$. Compared to the reported inhibition concentration of over $200 \mathrm{mg} / \mathrm{L}$ under thermophilic condition, the differences may be caused by: (i) smaller size of nano-NiO used in the mesophilic condition, which corresponded with the rate of releasing $\mathrm{Ni}^{2+}$ ions; (ii) utilisation of different substrates, wastewater had a relatively low volatile solid content and COD than that of glucose, which was associated with available biomass for bacteria; and (iii) the shifts of dominant hydrogen-producing bacterial groups under a range of temperature conditions, which led to changes in the upper limit of tolerant concentrations to nickel cations.

In contrast to the aforementioned iron-based nanoparticles, the stimulated impacts on fermentative AD processes are observed at low concentrations, implying the hydrogen-producing bacteria are more sensitive to released $\mathrm{Ni}^{2+}$ than iron cations.

\subsubsection{Non-trace-element-based nanoparticles}

Apart from nano- $\mathrm{TiO}_{2}$ and nano-Cu, most studied metal-based nanoparticles enhance the performance of $\mathrm{AD}$ fermentation at optimum concentrations by accelerating substrates to bio-hydrogen conversion (Pugazhendhi et al., 2019). More specifically, the only one publication interested in nano- $\mathrm{TiO}_{2}$ reported that it presenting limited influences on bio-hydrogen production (Hsieh et al., 2016), while nano-Cu is found to inhibit AD fermentation at all the dosages (Han et al., 2014; Mohanraj et al., 2016). 
363 The supplement of nano-Cu, declined the overall volume of fermentative bio-hydrogen owing to the release of $364 \mathrm{Cu}^{2+}$ cations (Han et al., 2014; Mohanraj et al., 2016). In addition, the nano-CuO particles provoked a higher 365 level of toxicity on the hydrogen-producing bacteria than the copper salts $\left(\mathrm{CuSO}_{4}\right)($ Mohanraj et al., 2016).

366 Particularly, Zhang et al. (2007) reported that at a concentration of $10 \mathrm{nM}$, the nano-gold particles with a 367 diameter of $5 \mathrm{~nm}$ have achieved the highest bio-hydrogen production, followed by 10nm-nano and 20nm-nano 368 gold particles. Moreover, an increase in the concentration of acetate, together with a reduction in propionate 369 and ethanol were observed. The findings imply that the smaller-sized nano-Au had greater impacts on altering fermentative type from butyrate only to butyrate/acetate by facilitating the hydrolysis process and stimulating key enzyme activities (Zhang and Shen, 2007).

\subsection{Influences on Methane-Production and Overall AD Processes}

In the past ten years, the influences from 22 metallic nano-additives on methane-production and overall $\mathrm{AD}$ processes were studied by researchers. According to results from quantitative analysis on methane production phase and overall AD process (Fig. 5), apart from nano-zinc, all the nano-additives based with trace elements were found to have positive influences on both methane-production and overall AD processes.

On the contrary, the influences from most (5 out of 9) nano-additives based with non-trace-element were reported only to have adverse impacts on either methane-production phase or overall AD processes. Researchers reported that nano- $\mathrm{TiO}_{2}$ was capable of enhancing the mitigation of hydrogen sulphide in harvested biogas and facilitating electron transfer between microbial species (Heinlaan et al., 2008; H. Li et al., 2017). Effluent quality was also improved by nano- $\mathrm{TiO}_{2}$ owing to the increase removal rate of volatile solids. Whilst the impacts from both nano- $\mathrm{Al}_{2} \mathrm{O}_{3}$ and $\mathrm{TiO}_{2}$ on the volume of produced gas (highlighted in purple boxes) were presented as "No observed" in the figure, which was due to offset of one study reported positive effects and the other study stated adverse impacts. This difference was associated with the selection of feedstock and dosage concentrations (Farghali et al., 2019; L. Zheng et al., 2019). Nonetheless, nano-silver was reported to have beneficial effects on absorbing inhibitory factors, including excessive amounts of sulphide. The impacts presented as "data missing" were owing to lack of experimental data from the selected publications for nano-additives.

The following Table 2 summarised the reported tolerate concentrations of the selected metallic nanoparticles if they only have adverse effects on either methane production stages and the overall AD processes. The reported concentrations for the metallic nanoparticles with the best performance during the AD process in terms of methane production were also included in this table. Similar to the findings for the AD fermentation phase, most of the nano-additives with iron-base had the highest reported tolerant concentrations up to $20 \mathrm{mg} / \mathrm{L}$. Whilst the appearance of nano-ZnO, as well as the nano-additives based with copper, provoked adverse impacts on the methane-production process at very low concentrations. More details were summarised in Supplementary 
397 Documents (see Supplementary Table S.4), and the mechanisms behind these observations were discussed in 398 the following sub-sections, where the metallic nanoparticles were grouped into "trace-element-based" and "non399 trace-element-based".

\subsubsection{Trace-element-based nanoparticles}

\section{- Iron-based nanoparticles}

Nano-scaled irons, together with its oxides and other composites, are the most prominent nano-additives used to boost the performance of anaerobic digesters owing to their low price, high conductivity, and strong reactivity, as well as the ability to release metallic nutrients for anaerobic microorganisms (Kato et al., 2012; Yamada et al., 2015; Zhou et al., 2014). All six types of iron nanoparticles have been reported to stimulate the AD process, enhance methane production, and improve effluent quality (Table S.4). The results varied between experiments because of differences in feedstock selection applied nanoparticles types and characteristics, as well as operating conditions. In terms of volume of generated methane, the maximum enhancement (increase by $387.1 \%$ ) was observed from the groups amended with nZVI (Pan et al., 2019), whilst for nano- $\mathrm{Fe}_{2} \mathrm{O}_{3}$ the highest improvement was only around $20 \%$ (Wang et al., 2016).

411 Compared with micro-sized iron-based additives, nano-iron-additives has a relatively higher surface-to-volume ratio, larger specific surface area and superior surface reactivity, which can serve to eliminate a wider range of 413 inhibition properties and pollutant species, including high abundance of ammonia, phosphorus and sulphate, 414 together with excessive amounts of heavy metals in wastewater treatment rapidly and thoroughly via 415 precipitation (Tareq W M Amen et al., 2017; Khalil et al., 2017; Wang et al., 2010, 2018b).

416 Focusing on the utilisation of nZVI in AD systems, 5 out of the selected 14 publications stated that the presence 417 of this nano-additive promoted the hydrolysis-acidification process by enhancing reduction of substrate and 418 facilitated the availability of degradable biomass for anaerobic microorganisms (Abdelsalam et al., 2017b, 419 2016b; Ma et al., 2019; Pan et al., 2019; Wang et al., 2018b). This is in agreement with the findings of Yu et al. 420 (2016), who observed increasing amounts of dissolved organic matter (DOM) species inside the sludge 421 fermentation liquor amended with nZVI. In subsequent studies, Amen et al. (2018) and Ambuchi et al. (2017) showed that the process of methanogenesis stage was also stimulated, as this nano-additive served as electron donors that could reduce carbon dioxide to methane.

Regarding the microbial community, dosing low concentrations of nZVI (below 200mg/L) (Wu et al., 2013) into the $\mathrm{AD}$ system could enrich the relative abundance of functional microorganisms involved in the processes of hydrolysis-acidogensis and methanogenesis (Pan et al., 2019; Wang et al., 2018a). Due to the facts that free sulphate sources in the liquid phase were immobilized by the production of ferrous sulphite $(\mathrm{FeS})$ and pyrite $\left(\mathrm{FeS}_{2}\right)$, the populations of sulphate-reducing bacteria (SRB) were decreased (Chaung et al., 2014), which is a group of microorganisms known as competitors of acetogens and methanogens using the same substrates inside 
431 AD system (St-Pierre and Wright, 2017), adding nZVI cannot only alter microorganism structure of AD process, 432 but also lower the hydrogen sulphide $\left(\mathrm{H}_{2} \mathrm{~S}\right)$ contents inside biogas,

433 As a strong reductant $\left(\mathrm{E}_{\mathrm{h}}=-0.44 \mathrm{~V}\right)$, the supplementation of $\mathrm{nZVI}$ into AD systems can rapidly reduce oxidation434 reduction potential (ORP) to maintain a reducing environment (Pan et al., 2019), and increase the production of 435 more energy favourable volatile fatty acids (VFAs) like acetic and butyric acids (Wang et al., 2018a). Since 436 both acidogensis phase and reactions between water and $\mathrm{Fe}^{0}$ particles from the dissolved nZVI can generate 437 hydrogen, which consequently increases hydrogen partial pressure, thus further limiting the production of 438 propionic acid (Wang et al., 2018b). Afterwards, there are two pathways to utilise the produced hydrogen. The 439 community of hydrogenotrophic methanogens catalyses the reaction of hydrogen and carbon dioxide to methane. 440 Alternatively, homoacetogenic archaea first convert the hydrogen to acetate, followed by break-downs of the 441 acetate leading to the rise of final methane contents (Zhen et al., 2015).

442 The amount of $\mathrm{Fe}^{0}$ particles dissociated from nZVI is decreased with the increase of particle sizes (Goldstein 443 et al., 1992; Talapin et al., 2001), but positively correlated with the surface-to-volume ratio that highly depends 444 on shapes of the particles (Abbas et al., 2013). In a study focusing on sludge in AD treatment responses to 445 nZVI (5-100nm) and ZVI (100 mesh, around $0.177 \mathrm{~mm}$ and 1000 mesh, around $0.015 \mathrm{~mm})$, all the three sizes of particles enhanced both the overall biogas production and methane yield, in which the 100 mesh ZVI achieved the most cumulative methane volume (Yu et al., 2016). However, only the addition of nZVI successfully reduced the final carbon dioxide contents below that of the control group (Yu et al., 2016). The released $\mathrm{Fe}^{2+}$ cations enriched the abundance of dominant hydrolysis-acidification microorganisms, such as Anaerolineae and Clostridia to generate more hydrogen, therefore stimulated the AD system generating methane from carbon dioxide via the two pathways as described above (Zhen et al., 2015).

On the other hand, the rapid dissolution of nZVI, which not only resulted in overproduction and accumulation of hydrogen that might inhibit acetoclastic methanogens (Zhen et al., 2015), but also led to high abundance of dissolved ferrous ions $\left(\mathrm{Fe}^{2+}\right.$ ) (Pan et al., 2019). The excessive amount of $\mathrm{Fe}^{2+}$ ions could combine with free phosphate ions $\left(\mathrm{PO}_{4}{ }^{3-}\right)$ or thiol groups ( $\left.\mathrm{R}-\mathrm{SH}\right)$ in the liquid to form stable complexes, hindering the phosphorus and sulphite uptake by methanogenic microbes, therefore inhibiting methanogenesis (Mu and Chen, 2011; Rudnick et al., 1990). Meanwhile, the high concentration of ferrous ions induced the production of reactive oxygen species (ROS) via the Fenton reaction (Tang and Lo, 2013), which were highly toxic to all types of microorganisms. Another possible mechanism behind the negative impacts from this nano-additive is the rapid coating of iron and ferric oxide $\left(\mathrm{Fe}(\mathrm{OH})_{3}\right)$ on the cells, which induces reductive stress, cell membrane structures disruption and cell lysis (Auffan et al., 2008; Lee et al., 2008; Marsalek et al., 2012).

462 The adverse effects of nZVI on the activities of microorganisms in anaerobic conditions provide a feasible 463 solution to kill bacteria that carry antibiotic resistance genes (ARGs), and harmful bacteria, such as Escherichia 464 coli (E. coli) during the AD process. The addition of nZVI could remove ARGs inside AD sludge by reducing amounts of MRGs without affecting the AD processes. Two studies reported that the addition of $80 \mathrm{mg} / \mathrm{L} \mathrm{nZVI}$ 
in antibiotics-containing wastewater raised the removal efficiency of ARGs over 50\% (Fang et al., 2011; Ma et al., 2019). Nonetheless, the relative abundance of most selected heavy metal resistance genes (MRGs) was simultaneously decreased, which were found having intimate genetic linkage with MRGs (L. G. Li et al., 2017), and horizontal gene transfer through MRGs was recognised as the main mechanism behind the transfer of ARGs between microorganisms (Pruden et al., 2006; Von Wintersdorff et al., 2016). Whereas the activities of the dominant microorganisms were enhanced at the same time, except the bacterial groups of Firmicutes (L. G. Li et al., 2017).

Regarding heavy metal removal, only one publication was found. In which, additions of both nZVI and nano$\mathrm{Fe}_{3} \mathrm{O}_{4}$ resulted in more than $95 \%$ of these heavy metal contents trapped within the solid phase (Suanon et al., 2016). Meanwhile, the concentrations of heavy metals in the forms (water-soluble, exchangeable, and carbonate-bound) that could be easily taken in by plants were significantly reduced. With the same dosage, nZVI had better performance in the removal of heavy metals than nano- $\mathrm{Fe}_{3} \mathrm{O}_{4}$, which only contributed to immobilisation of the heavy metals by physical and chemical absorptions. Whilst nZVI could trap heavy metals via redox reactions, absorption, and co-precipitation on the oxide shell formed around it (Suanon et al., 2016).

Iron oxide nanoparticles (IONPs) is a combination of maghemite $\left(\gamma-\mathrm{Fe}_{2} \mathrm{O}_{3}\right)$ and magnetite $\left(\mathrm{Fe}_{3} \mathrm{O}_{4}\right)$ particles with superparamagnetic properties (Ansari et al., 2019). Both Iron (II, III) oxide $\left(\mathrm{Fe}_{3} \mathrm{O}_{4}\right)$ and Iron (III) oxide $\left(\mathrm{Fe}_{2} \mathrm{O}_{3}\right)$ were recognised as essential nutrients for anaerobes activities in AD (Romero-güiza et al., 2016; Yang et al., 2013). Under anaerobic conditions, the iron oxides supply both ferrous ions $\left(\mathrm{Fe}^{2+}\right)$ and ferric ions $\left(\mathrm{Fe}^{3+}\right)$ slower than the abovementioned nZVI, owing to the fact that they are insoluble in the environment with neutral $\mathrm{pH}$ $(\mathrm{pH} \approx 7)$ (Weber et al., 2006). As a type of conductive material, the IONPs can still function as electron conduits of direct interspecies electron transfer (DIET) in their insoluble state between syntrophic, organic-oxidizing bacterial communities and $\mathrm{CO}_{2}$-reducing archaea groups (Mattioli and Bolzonella, 2016). Thereby, they can accelerate acetogenesis-methanogenesis, and raise final methane contents at lower concentrations (Wang et al., 2016).

The conductivity of nano-iron oxide was also proven to have effects on the methane-production stage (Kato et al., 2012). Both the conductive (nano- $\mathrm{Fe}_{3} \mathrm{O}_{4}$ ) and semi-conductive (nano- $\mathrm{Fe}_{2} \mathrm{O}_{3}$ ) nano-additives had similar stimulation impacts on $\mathrm{AD}$, including shorter lag phase and biogas production period, meanwhile boosting the methane production rate. However, the addition of insulative mineral (ferrihydrite) did not share these positive effects (Kato et al., 2012). The findings suggested that DIET was established between Geobacter and Methanosarcina by utilising conductive particles as electron conduits (Kato and Watanabe, 2010), thereby creating extracellular nanowires between anaerobic bacteria and archaea (Gorby et al., 2006; Reguera et al., 2005). Alternatively, the existence of conductive materials allowed electric syntrophy of microorganisms via direct contact (Agapova et al., 2010).

Utilising spinel ferrite (with a general formula of $\mathrm{AFe}_{2} \mathrm{O}_{4}$ ) nanoparticles for anaerobic digesters, especially the ones with trace elements like cobalt $\left(\mathrm{NiCoFe}_{2} \mathrm{O}_{4}\right)$ and nickel $\left(\mathrm{NiFe}_{2} \mathrm{O}_{4}\right)$, can produce more biomass for 
microorganisms and facilitate the activities of microorganisms, therefore increase the final biogas production (Lin et al., 2018). The stimulation impacts from spinel nano-additives released of nickel, cobalt, and iron cations as key factors for the formation of enzymes or coenzymes, as well as essential nutrients for microbes (Romerogüiza et al., 2016; Thauer et al., 2008). On the other hand, the exposure of AD to a strong, constant magnetic field created by nickel-zinc-ferrite nanostructures provoked inhibition of $\mathrm{AD}$ efficiency at very low concentrations (7mg/L) (Dębowski et al., 2016; Lin et al., 2018).

All the iron-based nano-additives shared some similar mechanisms behind these positive impacts, including: (i) release of bioavailable iron ions $\left(\mathrm{Fe}^{2+}\right.$ and $\left.\mathrm{Fe}^{3+}\right)$, which is known as an essential nutrient for microbial power generation, DNA replication (Zaidi et al., 2018) and key enzymes formation (Zhang et al., 2018), therefore increase microbial abundance and activities of key enzymes or co-enzymes, (ii) serve as conduits for electrons, hence stimulate electron transfer (both interspecies electron transfer, IET and direct interspecies electron transfer, DIET) between the bacterial and archaeal communities (Lovley, 2017), and (iii) absorb inhibitory compounds and works as a pH buffer, thus stabilise the AD system (Lei et al., 2018; J. Zhang et al., 2019). Finally, all the publications concluded that the influences on the AD process from nano-iron-additives were dosage-dependent. Excessive dosage of iron-based nanoparticles hindered the overall process resulting in reductions of biogas production.

\section{- Zinc-based nanoparticles}

The antibacterial characteristic of $\mathrm{ZnO}$ nanoparticles can be utilized to prevent the growth of coliform bacteria in wastewater treatment (Mostafaii et al., 2017; X. Zheng et al., 2019). Although the addition of nano-zinc into anaerobic digesters does not have direct influences on the structure of bacteria, it still presents inhibitory impacts to the growth of the hydrolysis and acidification bacteria, such as Firmicutes and Bacteroidetes. The activities of key enzymes and coenzymes, including protease, acetate kinase (AK) and $\mathrm{F}_{420}$ are also hindered by the addition of nano-zinc (Zheng et al., 2015). Additionally, the addition of zinc oxide nanoparticles slightly enriched most of the hydrogenotrophic methanogens (Zhao et al., 2019). While all the acetoclastic methanogenesis were prohibited by nano-ZnO besides Methanosarcinaseae (Zhao et al., 2019) since the acetoclastic methanogens were more sensitive to this particle compared with hydrogenotrophic methanogens (Gonzalez-Estrella et al., 2013).

The supplementation of nano-ZnO in liquid swine treatment under anaerobic conditions shrunk the volume of emitted hydrogen sulphide $\left(\mathrm{H}_{2} \mathrm{~S}\right)$ in the gas stream by $99 \%$ by forming zinc sulphide $(\mathrm{ZnS})$ as described in Eq.4 (Gautam et al., 2017). The produced hydrogen sulphide was first dissolved in water, then dissociated into hydrogen ions $\left(\mathrm{H}^{+}\right)$and bisulphide ions $\left(\mathrm{HS}^{-}\right)$. Afterwards, the $\mathrm{HS}^{-}$anions diffused into the nanoparticles, and were finally chemisorbed by the hydroxide $\left(\mathrm{OH}^{-}\right)$groups on the $\mathrm{ZnO}$ particle surface (Song et al., 2013). The overall production of biogas was decreased, with a reduction of $72 \%$ of methane $\left(\mathrm{CH}_{4}\right)$ and $62 \%$ of carbon dioxide $\left(\mathrm{CO}_{2}\right)$ volumetrically at the same time(Gautam et al., 2017).

$$
\mathrm{ZnO}+\mathrm{H}_{2} \mathrm{~S} \rightarrow \mathrm{ZnS}+\mathrm{H}_{2} \mathrm{O}
$$


Most of the existing studies (7 out of 12) found that the influences on the AD process due to exposure of zinc oxide $(\mathrm{ZnO})$ nanoparticles were dosage-dependent. The presence of nano- $\mathrm{ZnO}$ at low concentrations in anaerobic digesters did not inhibit their process completely. On the contrary, it was reported to have slightly stimulating effects on protein solubilisation (Zhang et al., 2017). At low concentrations (1mM), though the addition of nano- $\mathrm{ZnO}$ gave adverse effects on anaerobic digestion treated model organic wastes, such as a longer lag phase and biogas production period, as well as reduction of maximum daily methane production rate to around half of the control (Zhu et al., 2019). In addition, the AD system can overcome the antagonistic impacts by either absorbing the nanoparticles with organics followed by precipitation, or changing the surface charge of nano- $\mathrm{ZnO}$ to neutral or negative. Therefore, after a short ( 2 days) hinder period the AD system became stable with a slight increase (2.19\%) in final methane production (Zhu et al., 2019). Beyond this tolerate concentration, the addition of nano-ZnO blocked the $\mathrm{AD}$ process completely due to the change of archaeal community structure and VFA accumulation (Mu et al., 2011).

The main reason for the adverse effects on methane production from the AD system is the release of $\mathrm{Zn}^{2+}$ cations from zinc oxide nanoparticles ( $\mathrm{Mu}$ and Chen, 2011), when its concentration gradually increases during the AD process over time. However, as zinc oxide has low aqueous solubility (Karlsson et al., 2009), the adverse influences on gas production highly rely on the differences in particle surface and characteristics of nano-ZnO once the concentration reached a certain level (Luna-delRisco et al., 2011).

In the only one study related to the removal rate of ARGs after the AD process amended with nano-ZnO, Huang et al. (2019) found that after operation for 100 days, the overall abundance of ARGs increased by $28 \%$ comparing with the control sample. Additionally, both abundance and diversities of the mobile genetic elements (MGEs) were increased by the presence of these nanoparticles, which might serve as carriers of the ARGs with better mobility. The exposure of nano- $\mathrm{ZnO}$ triggered signal transduction from cell to cell, facilitated horizontal gene transfer (HGT), also enriched some of the genera that acted as hosts of ARGs (Lactones et al., 2004; Tan et al., 2014; Valle et al., 2004).

The toxicity of nano-ZnO on AD microorganisms can be attenuated by co-addition of biogenic or iron sulphide $(\mathrm{FeS})$, leading to a displacement reaction to form zinc sulphide $(\mathrm{ZnS})$ and release of metallic nutrients including iron cations $\left(\mathrm{Fe}^{2+}\right)$ (Gonzalez-Estrella et al., 2016, 2015b). Alternatively, pre-treat the nano-ZnO in order to immobilize and stabilise them with biogenic solutions, such as sodium alginate solution and methylenebisacrylamide before dosing them at low concentration into the AD system (Ahmad and Reddy, 2019; Gautam et al., 2017). Moreover, in comparison to the wet AD system, the supplementation of nano-ZnO into solid waste anaerobic digesters was less harmful to the process under similar concentrations (Eduok, 2015).

\section{- Other trace-element-based nanoparticles}

All the metal nano-additives with trace elements present enhancements to the AD process concerning the amount of biomass produced from substrate, VFAs yield, lag phase period, enzymes and co-enzymes production, as well as the volume of gas yield at low concentration. In particular, nano-Co and Ni not only shortened the 
length of the lag phase, but also increased the time required to achieved the peak of gas production (Abdelsalam et al., 2016b).

The group amended with $2 \mathrm{mg} / \mathrm{L}$ nano-Co gave adverse influences in the volume of biogas yield, demonstrating slight inhibition on methanogenic microorganisms, while the group treated with nano-Ni at the same concentration generated the most amount of methane, as well as biogas (Abdelsalam et al., 2016b). The experiment using manure as substrate created a sulphite-rich environment (Manitoba Agriculture, 2015), where the dissolved amount of measured cobalt cations was significantly higher than the estimated concentration based on the equilibrium constant (Gustavsson et al., 2013). Furthermore, the high sulphite content in AD sludge may cause the formation of metal sulphites, and thus lead to sulphide precipitation and restrains in trace element potential bioavailability. The bioavailability and bioreactivity of metallic nutrients to microorganisms is tightly associated with the metal fractions. Whilst the accessibility of metal fractions is in order of water-soluble, exchangeable, acid-soluble, oxidizable (organic and sulphide-bound), and residual (Jia et al., 2017; Yekta et al., 2017). Base on this fact, the influences on the bioavailability of nickel were lower in sulphite-rich environments, and nickel-sulphite can work as storage of nickel (Jansen et al., 2007) and provide metallic nutrient at a slower pace than cobalt.

With high concentration (500 mg/g TSS) of nano-MgO led to inhibition of the anaerobic digesters treated waste activated sludge completely, and finally led to a reduction of $98.92 \%$ in methane production (Wang et al., 2016). The primary reason behind this was the release of excessive amounts of $\mathrm{Mg}^{2+}$ cations, which is consistent with damage in cell membranes and loss of key enzymatic activities (Wang et al., 2016).

\subsubsection{Non-trace-element-based Nanoparticles}

The studies on nano- $\mathrm{Ag}^{0}, \mathrm{Al}_{2} \mathrm{O}_{3}, \mathrm{CeO}_{2}$, and $\mathrm{TiO} 2$ did not report any notable effects on $\mathrm{AD}$ performance with the tolerate concentrations up to $1500 \mathrm{mg} / \mathrm{L}$ (Gonzalez-Estrella et al., 2013; Mu et al., 2011). In contrast to these findings, Ünşar et al. (Ünşar et al., 2016) reported a slight inhibition from the addition of $150 \mathrm{mg} / \mathrm{g}$ TS nano$\mathrm{Ag}$ on $\mathrm{AD}$ of waste activated sludge (WAS). The differences in the results might be induced by changes in size ranges and substrate. Whereas, adverse influences from manganese(III) oxide $\left(\mathrm{Mn}_{2} \mathrm{O}_{3}\right)$ nanoparticles with high concentrations $(1500 \mathrm{mg} / \mathrm{L})$ on methane production was observed, but the mechanisms behind the responses still needed further investigation (Gonzalez-Estrella et al., 2013).

Nano- $\mathrm{Cu}^{0}$ and nano-CuO caused severe inhibition on methanogenesis that is mainly attributed to the release of $\mathrm{Cu}^{2+}$ ions (H. Li et al., 2017). The dosage of $100 \mathrm{mg} / \mathrm{L}$ of nano- $\mathrm{Cu}^{0}$ completely blocked the hydrogenotrophic methanogenesis pathway after two generations, while the methane production from the acetoclastic methanogenic pathway was around half of that of the control group (Gonzalez-Estrella et al., 2013). This result demonstrated that the hydrogenotrophic methanogens were more sensitive to copper cations $\left(\mathrm{Cu}^{2+}\right)(\mathrm{Chen}$ et al., 2008; Luna-delRisco et al., 2011). Moreover, the nitrogen and phosphorus removal efficiencies were evidently affected by high concentrations of nano- $\mathrm{CuO}$ addition, as the nanoparticles prevented the activities of enzymes, damaged cell membranes, and thus caused cell lysis of the microorganisms (Wang et al., 2017). Similar to the 
aforementioned $\mathrm{ZnO}$ nanoparticles, nano- $\mathrm{CuO}$ at concentrations of $20 \mathrm{mg} / \mathrm{g}$ TSS also activated the cell-to-cell

607 signal transfer, especially quorum sensing. While MGEs were enriched and horizontal gene transfer (HGT) was 608 also promoted by nano-CuO, therefore, stimulated the propagation of ARGs (Huang et al., 2019).

609 Regarding the low dispersion properties of nano- $\mathrm{CeO}_{2}$ inside the aqueous medium, this type of nanoparticle was 610 more likely to precipitate then dissolve into AD sludge. As a result, the change of reduction in the volume of 611 biogas was insignificant with the increase in the concentration of this type of nano-additive from 100 to 1000 $612 \mathrm{mg} / \mathrm{L}$ in the AD of model substrate solution and anaerobic sludge (Nguyen et al., 2015). The upper limit of 613 dosage concentration of nano- $\mathrm{CeO}_{2}$ for mesophilic $\mathrm{AD}$ microorganisms was below $0.16 \mathrm{mg} / \mathrm{mL}$ (García et al., 614 2012). Particularly, nano- $\mathrm{CeO}_{2}$ at low exposure concentrations could increase the AD performance in terms of 615 biogas yield and removal efficiency of COD in the effluent (Nguyen et al., 2015). The positive impact is believed 616 to be attributed to the released $\mathrm{Ce}^{4+}$ and $\mathrm{Ce}^{3+}$ ions, which could covert toxic ROS into oxygen and water (Xia et 617 al., 2008).

618 With regard to the silver-based nanoparticles, despite the toxicity on AD microorganisms from the released $\mathrm{Ag}^{+}$ 619 ions (Yang et al., 2012a), the surface charge of the particles was another factor affecting their impacts on AD. 620 The nano-Ag with negative or neutral surface charge were stabilised in either solid phase or liquid medium and 621 thus did not inhibit the AD process (Gitipour et al., 2016). Additionally, over 90\% of the PVP coated nano-Ag were removed from sludge after AD treatment (Doolette et al., 2013). For the particles with positive surface charge, they were more likely to interact with microorganism communities that were negatively charged, and thus obtained higher toxicity. Moreover, the release of silver cations depleted sulphite existing inside AD sludge by forming $\mathrm{Ag}_{2} \mathrm{~S}$, leading to inhibition of the microorganisms that relied on sulphite as essential nutrients (Doolette et al., 2013; Gitipour et al., 2016; Mu and Chen, 2011; Rudnick et al., 1990). As for anaerobic digesters treating dry waste, the addition of nano- $\mathrm{Ag}$ at a concentration of $10 \mathrm{mg} / \mathrm{kg}$ of solid, caused accumulation of VFAs, and thus reduced the population of archaeal communities, which could not survive in acid environments (Yang et al., 2012b).

630 As an insoluble nanoparticle, the releasing ion concentration from nano- $\mathrm{TiO}_{2}$ into aqueous medium is negligible under anaerobic neutral conditions. Hence, it does not present any significant impact on the harvest of biohydrogen or biogas (Hsieh et al., 2016). In this case, the possible mechanisms behind the inhibitory impacts are the aggregation of these nanoparticles on the sludge surface, which leads to less active sites and reduced surface area for bacteria responsible for fermentation, hence decreases the viability of biomass for microorganisms in the following phases (Heinlaan et al., 2008; H. Li et al., 2017). 
640 Only the impacts from 7 types of metallic nanoparticles were studied for both research interests (AD 641 fermentation phase, methane-production and overall AD processes) in the past ten years. Fig. 6 illustrates the 642 differences between reported tolerate concentrations for both research interests, while all the units for dosage 643 concentration are converted into $\mathrm{mg} / \mathrm{L}$. Of notice, the reported tolerate concentration of nano- $\mathrm{ZnO}$ still led to 644 adverse effects on the methane-production stage and overall AD process (Zhu et al., 2019), thereby the actual 645 tolerate concentration of nano- $\mathrm{ZnO}$ was much lower than $1 \mathrm{mM}$.

646 Apart from nano- $\mathrm{ZnO}$ and nano- $\mathrm{Cu}$, the reported tolerated concentrations of all the metallic nanoparticles for the $\mathrm{AD}$ fermentation phase were higher than that of the methane-production stage and overall $\mathrm{AD}$ phase. This

648 indicates that the methane-producing archaea, as well as acetogenesis bacteria are more sensitive to the addition 649 of nanoparticles than hydrogen-producing bacteria under the same concentration (H. Li et al., 2017). 650 Furthermore, the presence of nano-Cu prohibited both hydrogen-production and methane-production stages.

\subsection{Influences from Multi-nanoparticles}

653 Dosing multi nano-additives, especially nano-additives that are trace elements based, into anaerobic digesters normally provokes synergistic effects, resulting in further improvement in either the AD fermentative system or whole AD process (see Supplementary Table S.5). Moreover, the AD system amended with nano- $\mathrm{TiO}_{2}$ has been observed to have diminished impacts on inhibition owing to excessive amounts of $\mathrm{ZnO}$ nanoparticle addition (L. Zheng et al., 2019).

Co-addition of nano- $\mathrm{Fe}_{2} \mathrm{O}_{3}$ and nano-NiO incurs enhancement in bio-hydrogen production from $\mathrm{AD}$ fermentation of wastewater and anaerobic sludge (Gadhe et al., 2015). With the same exposure concentration of nano- $\mathrm{Fe}_{2} \mathrm{O}_{3}$, when the concentration of nano- $\mathrm{NiO}$ dosed in the multi-nanoparticles system was below $5 \mathrm{mg} / \mathrm{L}$, the amount of bio-hydrogen increased linearly. Whereas, if the nano-NiO loading went over $5 \mathrm{mg} / \mathrm{L}$, the stimulating impacts were prevented, which corresponded with the abovementioned tolerant concentration of nano-NiO in the fermentative AD process (Gadhe et al., 2015).

In comparison to the system amended with single nano-additive, a co-addition system can undertake higher tolerant concentrations for each nano-additive. For instance, Taherdanak et al. (2015) demonstrated inhibitory impacts in $\mathrm{AD}$ fermentation with dosages of $25 \mathrm{mg} / \mathrm{L} \mathrm{nZVI}$ or $25 \mathrm{mg} / \mathrm{L}$ nano-Ni ${ }^{0}$. However, under co-addition conditions, adding $37.5 \mathrm{mg} / \mathrm{L} \mathrm{nZVI}$ together with nano- $\mathrm{Ni}^{0}$ at the same concentration could significantly improve the fermentative performance (Taherdanak et al., 2015). Although adding multi-nanoparticles based with trace elements did not bring striking improvements in methane production, in fact, they caused a notable reduction in hydrogen sulphide contents (Hassanein et al., 2019).

The surface of $\mathrm{TiO}_{2}$ can serve as a perfect site to absorb free ions in $\mathrm{AD}$ sludge that have negative impacts on the process, such as $\mathrm{Zn}^{2+}$ via relevant reactions as expressed in Eq. 5, hence attenuating the antagonistic effects from $\mathrm{ZnO}$ nanoparticles (Tong et al., 2014). In this case, the $\mathrm{AD}$ system applied with both $\mathrm{ZnO}$ and $\mathrm{TiO}_{2}$ 
674 nanoparticles presented better performance than the one only supplied with nano- $\mathrm{ZnO}$ at the same concentration.

675 The AD system amended with both nanoparticles presented less extracellular LDH production, higher VFAs to 676 the methane consumption rate, as well as increasing acetic acid yield with facilitating influences on the activities 677 of both protease and acetate kinase in comparison with single-additive systems (L. Zhang et al., 2019; L. Zheng 678 et al., 2019). The results further proved that with the help of $\mathrm{TiO}_{2}$ nanoparticles, the $\mathrm{AD}$ system could overcome 679 the inhibitory impacts caused by the presence of $\mathrm{ZnO}$ Nanoparticles due to released zinc cations.

$$
\mathrm{Zn}^{2+}(\mathrm{aq})+\equiv \mathrm{TiOH}(\mathrm{s}) \rightleftarrows \equiv \mathrm{TiOZn}^{2+}(s)+\mathrm{H}^{+}(a q)
$$

Where $\equiv$ emphasizes that the adsorption occurs on the surface of nano- $\mathrm{TiO}_{2}$.

\section{Summary and Future Research Prospects}

Almost all kinds of nano-additives with trace elements have been proved that they can be used to improve AD performances by different approaches at low concentrations, including: (i) altering AD microbial structure; (ii) releasing metallic nutrients; (iii) producing more biomass by facilitating substrate bio-degradability; as well as (iv) absorbing excessive amounts of inhibitory factors like heavy metals. Among them, $\mathrm{ZnO}$ nanoparticles and cobalt nanoparticles presented adverse impacts on biogas or methane yield at relatively low dosage concentrations, as the dominant metal fractions of them inside AD can be easily uptaken by microorganisms (in forms of water-soluble, exchangeable, acid-soluble and oxidizable), and thus excesses the tolerance limits.

Meanwhile, the addition of most non-trace elements-based metal nano-additives into the AD process does not show noticeable influences. However, with the increase in concentrations, all of them exhibit negative effects on gas production rate and leading to a reduction in the overall amount of gas yield. The reasons behind the toxic influences may either cause by nanoparticle aggregation, which builds physical barriers on the anaerobic sludge surface to prevent reactions, or due to the release of excessive toxic cations causing production of ROS and damages on cell integrity.

The application of metallic additives in nano-size implies more significant influences on the AD process compare with bulk size additives. The nanoparticles are observed to stick on the surface of anaerobic sludge due to their negative surface charges, then these nanoparticles are easier to penetrate through cell membranes, breakdown complex organics, produce more biomass for microorganisms, and thus facilitate metabolism in the following phases of $\mathrm{AD}$. While the impacts from these metallic nanoparticles on the $\mathrm{AD}$ process tightly correspond with their released free ions. While the differences in influences of metallic nanoparticles on the AD process not only associated with the types of species based on chemical forms, but also attributed to a number of factors like particle characteristics (sizes, shapes, surface area, and surface charge), dispersion degree and stability. 
Besides, the AD system supplementation with multi-nano-additives achieves better performance with a dramatic increase in methane production or overcome some of the negative impacts. In particular, nano- $\mathrm{TiO}_{2}$ in the multiadditives system trapped the inhibitory elements, such as excessive amounts of sulphite and zinc ions. Whereas, the system amended with multi-nano-trace element presents synergistic effects.

712 Future work in this area needs to obtain a better understanding of nano-additives roles in anaerobic digesters and their speciation, together with the factors affecting their bioavailability and bioreactivity through $\mathrm{AD}$ process:

1. In most of the current literature, the amount of gas production was used as the only indicator to justify the effects of metal nano-additives on the AD process. As the other important output from anaerobic digesters, the changes in effluent quality after amending with nano-additives requires further investigation. In addition, the researches on change in microbial structure, as well as the quality of the generated gas also need to be taken into account.

2. Most of the studies on nano-additives have carried out by batch experiments. Further studies on feasibility of adding these nano-additives in other anaerobic reactor configurations are required, and experiments operated in different environment need to be addressed clearly.

3. The experiment designs from existing publications are mostly used for indicating the impacts of shortterm exposure. However, if the dosed concentration of these nanoparticles is below tolerant concentration, the AD system may require time to recover by themselves. In this case, results from long-term exposure tests are closer to reality, which can be obtained by semi-continuous and continuous tests.

4. Further studies are required to find out the tolerant concentrations of the metallic nanoparticles on AD with different substrate and inoculum regarding volatile solids.

5. A more in-depth study is also required to verify the metal fractions and bioavailability under anaerobic conditions. Moreover, further research on the synergistic effects achieve by multi-nanoparticles on metal specification, especially the formation of metal sulphides in the sulphite-rich environment is also demanded.

6. It is still not clear in the literature about influences due to differences in particle characteristics of nanoadditives with the same chemical components, as well as the depression degree and stability of the nanoparticles in the liquid phase. Thereby, a series of experiments should be carried out to determine an optimal size range, the optative shapes, and the best dispersion solution, as well as suitable pretreatment for each metallic nano-additive.

7. Development of procedures to regulate the studies that justify the nanoparticles' impacts on the AD process and its outputs, including feedstock combinations and indicators selections.

8. Lastly, research is still required on the differences in mechanisms behind the improvement in dark fermentative $\mathrm{AD}$ performance with additions of nano-additives with photocatalysis characteristics, such as hematite $\left(\alpha-\mathrm{Fe}_{2} \mathrm{O}_{3}\right)$ and titanium oxide $\left(\mathrm{TiO}_{2}\right)$, and the ones without this feature. 


\section{Conclusions}

747 The supplementation of metallic nanoparticles into the $\mathrm{AD}$ system presents notable influences on the 748 performance of $\mathrm{AD}$ regarding process stability, gas production, as well as effluent quality. Recently, extensive 749 research on impacts on the AD process from these nanoparticles, especially the ones with trace element based 750 have pointed out the feasibility of applying some of them in reality. Nonetheless, the solutions to overcome 751 inhibition from existing nanoparticles inside anaerobic digesters, such as nano- $\mathrm{ZnO}, \mathrm{Ag}$, and $\mathrm{CuO}$ still need 752 further investigations. As for microbial communities, methane-producing archaea are more sensitive to the 753 addition of nanoparticles than hydrogen-producing bacteria under the same concentration. The toxic impacts of 754 the metallic nanoparticles to AD microorganisms are dosage-dependent and are largely dependent on their 755 characteristics and fractions in AD sludge. By understanding the impacts from both single-addition and co756 addition of different metallic-based nanoparticles, some industrial by-products in nanoscale, such as fly ash (FA) 757 can be applied to monitor the performance of anaerobic digesters. 


\section{References}

Abbas, M., Takahashi, M., Kim, C., 2013. Facile sonochemical synthesis of high-moment magnetite (Fe 3O4) nanocube. J. Nanoparticle Res. 15. https://doi.org/10.1007/s11051-012-1354-y

Abdelsalam, E., Samer, M., Attia, Y.A., Abdel-hadi, M.A., Hassan, H.E., Badr, Y., 2017a. Effects of Co and Ni nanoparticles on biogas and methane production from anaerobic digestion of slurry. Energy Convers. Manag. 141, 108-119. https://doi.org/10.1016/j.enconman.2016.05.051

Abdelsalam, E., Samer, M., Attia, Y.A., Abdel-hadi, M.A., Hassan, H.E., Badr, Y., 2017b. In fl uence of zero valent iron nanoparticles and magnetic iron oxide nanoparticles on biogas and methane production from anaerobic digestion of manure. Energy 120, 842-853. https://doi.org/10.1016/j.energy.2016.11.137

Abdelsalam, E., Samer, M., Attia, Y.A., Abdel-Hadi, M.A., Hassan, H.E., Badr, Y., 2016a. Comparison of nanoparticles effects on biogas and methane production from anaerobic digestion of cattle dung slurry. Renew. Energy 87, 592-598. https://doi.org/10.1016/j.renene.2015.10.053

Abdelsalam, E., Samer, M., Attia, Y.A., Abdel-Hadi, M.A., Hassan, H.E., Badr, Y., 2016b. Comparison of nanoparticles effects on biogas and methane production from anaerobic digestion of cattle dung slurry. Renew. Energy 87, 592-598. https://doi.org/10.1016/j.renene.2015.10.053

Acharya, G., Mitra, A.K., Cholkar, K., 2017. Nanosystems for Diagnostic Imaging, Biodetectors, and Biosensors, Emerging Nanotechnologies for Diagnostics, Drug Delivery and Medical Devices. Elsevier. https://doi.org/10.1016/B978-0-323-42978-8.00010-3

Achiba, W. Ben, Lakhdar, A., Gabteni, N., Laing, G. Du, Verloo, M., Boeckx, P., Van Cleemput, O., Jedidi, N., Gallali, T., 2010. Accumulation and fractionation of trace metals in a Tunisian calcareous soil amended with farmyard manure and municipal solid waste compost. J. Hazard. Mater. 176, 99-108 https://doi.org/10.1016/j.jhazmat.2009.11.004

Agapova, O.A., Harbour, J.W., Worley, L.A., Tuscan, M.D., Harbour, J.W., Force, T., Machida, Y., Vashisht, A.A., Wohlschlegel, J.A., Dutta, A., Chabes, A.L., Wysocka, J., Herr, W., Worley, L.A., Ehlers, J.P., Harbour, J.W., Foundation, Hospital, Foundation, K.F., Foundation, Horncrest, Blindness, P., Weeks, D.F., Blindness, P., 2010. Direct Exchange of Electrons Within Aggregates of an Evolved Syntrophic Coculture of Anaerobic Bacteria 1413-1416.

Ahmad, A., Reddy, S.S., 2019. Performance evaluation of upflow anaerobic sludge blanket reactor using immobilized $\mathrm{ZnO}$ nanoparticle enhanced continuous biogas production. Energy Environ. https://doi.org/10.1177/0958305X19865967

Ali, A., Mahar, R.B., Soomro, R.A., Hussain, S.T., 2017. Fe3O4 nanoparticles facilitated anaerobic digestion of organic fraction of municipal solid waste for enhancement of methane production. Energy Sources, Part A Recover. Util. Environ. Eff. 39, 1815-1822. https://doi.org/10.1080/15567036.2017.1384866 
Alvarado, A., Montañez-hernández, L.E., Palacio-molina, S.L., Oropeza-navarro, R., Miriam, P., 2014. Microbial trophic interactions and mcr A gene expression in monitoring of anaerobic digesters 5, 1-14. https://doi.org/10.3389/fmicb.2014.00597

Ambuchi, J.J., Zhang, Z., Shan, L., Liang, D., Zhang, P., Feng, Y., 2017. Response of anaerobic granular sludge to iron oxide nanoparticles and multi-wall carbon nanotubes during beet sugar industrial wastewater treatment. Water Res. 117, 87-94. https://doi.org/10.1016/j.watres.2017.03.050

Amen, Tareq W M, Eljamal, O., Khalil, A.M.E., Matsunaga, N., 2017. Biochemical methane potential enhancement of domestic sludge digestion by adding pristine iron nanoparticles and iron nanoparticles coated zeolite compositions. J. Environ. Chem. Eng. 5, 5002-5013. https://doi.org/10.1016/j.jece.2017.09.030

Amen, Tareq W.M., Eljamal, O., Khalil, A.M.E., Matsunaga, N., 2017. Evaluation of nano zero valent iron effects on fermentation of municipal anaerobic sludge and inducing biogas production. IOP Conf. Ser. Earth Environ. Sci. 67. https://doi.org/10.1088/1755-1315/67/1/012004

Amen, T.W.M., Eljamal, O., Khalil, A.M.E., Sugihara, Y., 2018. Process Intensification Methane yield enhancement by the addition of new novel of iron and copper-iron bimetallic nanoparticles 130, 253-261. https://doi.org/10.1016/j.cep.2018.06.020

Ansari, S.A.M.K., Ficiarà, E., Ruffinatti, F.A., Stura, I., Argenziano, M., Abollino, O., Cavalli, R., Guiot, C., D’Agata, F., 2019. Magnetic iron oxide nanoparticles: Synthesis, characterization and functionalization for biomedical applications in the Central Nervous System. Materials (Basel). 12. https://doi.org/10.3390/ma12030465

Arbiol, J., Font, X., Busquets-Fité, M., González, E., Barrena, R., Glatzel, P., Sánchez, A., Casals, E., García, A., Delgado, L., Puntes, V., Kvashnina, K., 2014. Programmed Iron Oxide Nanoparticles Disintegration in Anaerobic Digesters Boosts Biogas Production. Small 10, 2801-2808. https://doi.org/10.1002/smll.201303703

Arif, S., Liaquat, R., Adil, M., 2018. Applications of materials as additives in anaerobic digestion technology. Renew. Sustain. Energy Rev. 97, 354-366. https://doi.org/10.1016/j.rser.2018.08.039

Auffan, M., Achouak, W., Rose, J., Roncato, M.A., Chanéac, C., Waite, D.T., Masion, A., Woicik, J.C., Wiesner, M.R., Bottero, J.Y., 2008. Relation between the redox state of iron-based nanoparticles and their cytotoxicity toward Escherichia coli. Environ. Sci. Technol. 42, 6730-6735. https://doi.org/10.1021/es800086f

Bajpai, P., 2017. Basics of Anaerobic Digestion Process, in: Anaerobic Technology in Pulp and Paper Industry. pp. 7-13. https://doi.org/10.1007/978-981-10-4130-3

Beiki, H., Keramati, M., 2019. Improvement of Methane Production from Sugar Beet Wastes Using $\mathrm{TiO}_{2}$ and 
$\mathrm{Fe}_{3} \mathrm{O}_{4}$ Nanoparticles and Chitosan Micropowder Additives.

Bharathiraja, B., Sudharsanaa, T., Bharghavi, A., Jayamuthunagai, J., Praveenkumar, R., 2016. Biohydrogen and Biogas - An overview on feedstocks and enhancement process. Fuel 185, 810-828. https://doi.org/10.1016/j.fuel.2016.08.030

Boer, J.L., Mulrooney, S.B., Hausinger, R.P., 2014. Nickel-dependent metalloenzymes. Arch. Biochem. Biophys. 544, 142-152. https://doi.org/10.1016/j.abb.2013.09.002

Chaung, S., Wu, P., Kao, Y., Yan, W., Lien, H., 2014. Nanoscale Zero-Valent Iron for Sulfide Removal from Digested Piggery Wastewater 2014.

Chen, R., Konishi, Y., Nomura, T., 2018. Enhancement of methane production by Methanosarcina barkeri using $\mathrm{Fe} 3 \mathrm{O} 4$ nanoparticles as iron sustained release agent. Adv. Powder Technol. 29, 2429-2433. https://doi.org/10.1016/j.apt.2018.06.022

Chen, Y., Cheng, J.J., Creamer, K.S., 2008. Inhibition of anaerobic digestion process: A review. Bioresour. Technol. 99, 4044-4064. https://doi.org/10.1016/j.biortech.2007.01.057

Chipasa, K.B., 2003. Accumulation and fate of selected heavy metals in a biological wastewater treatment system. Waste Manag. 23, 135-143. https://doi.org/10.1016/S0956-053X(02)00065-X

Dar, S.A., Kleerebezem, R., Stams, A.J.M., Kuenen, J.G., Muyzer, G., 2008. Competition and coexistence of sulfate-reducing bacteria, acetogens and methanogens in a lab-scale anaerobic bioreactor as affected by changing substrate to sulfate ratio. Appl. Microbiol. Biotechnol. 78, 1045-1055. https://doi.org/10.1007/s00253-008-1391-8

Dębowski, M., Zieliński, M., Kisielewska, M., Hajduk, A., 2016. Effect of constant magnetic field on anaerobic digestion of algal biomass. Environ. Technol. (United Kingdom) 37, 1656-1663. https://doi.org/10.1080/09593330.2015.1126362

Demirel, B., Göl, N.P., Onay, T.T., 2013. Evaluation of heavy metal content in digestate from batch anaerobic co-digestion of sunflower hulls and poultry manure. J. Mater. Cycles Waste Manag. 15, 242-246. https://doi.org/10.1007/s10163-012-0107-4

Ding, J., Wang, X., Zhou, X.F., Ren, N.Q., Guo, W.Q., 2010. CFD optimization of continuous stirred-tank (CSTR) reactor for biohydrogen production. Bioresour. Technol. 101, 7005-7013. https://doi.org/10.1016/j.biortech.2010.03.146

Dong, D., Aleta, P., Zhao, X., Kyung, O., Kim, S., Woo, J., 2019. Effects of nanoscale zero valent iron (nZVI) concentration on the biochemical conversion of gaseous carbon dioxide $\left(\mathrm{CO}_{2}\right)$ into methane $\left(\mathrm{CH}_{4}\right)$. Bioresour. Technol. 275, 314-320. https://doi.org/10.1016/j.biortech.2018.12.075

Doolette, C.L., McLaughlin, M.J., Kirby, J.K., Batstone, D.J., Harris, H.H., Ge, H., Cornelis, G., 2013. Transformation of PVP coated silver nanoparticles in a simulated wastewater treatment process and the 
effect on microbial communities. Chem. Cent. J. 7, 1-18. https://doi.org/10.1186/1752-153X-7-46

Eduok, S., 2015. Zinc oxide nanoparticle impact on solid waste anaerobic digestion and biogas production. J. Environ. Earth Sci. 5, 142-149.

Elreedy, A., Fujii, M., Koyama, M., Nakasaki, K., Taw, A., 2019. Enhanced fermentative hydrogen production from industrial wastewater using mixed culture bacteria incorporated with iron, nickel, and zinc-based nanoparticles 151, 349-361. https://doi.org/10.1016/j.watres.2018.12.043

Fagbohungbe, M.O., Herbert, B.M.J., Hurst, L., Ibeto, C.N., Li, H., Usmani, S.Q., Semple, K.T., 2017. The challenges of anaerobic digestion and the role of biochar in optimizing anaerobic digestion. Waste Manag. 61, 236-249. https://doi.org/10.1016/j.wasman.2016.11.028

Fang, Z., Chen, J., Qiu, Xinhong, Qiu, Xiuqi, Cheng, W., Zhu, L., 2011. Effective removal of antibiotic metronidazole from water by nanoscale zero-valent iron particles. Desalination 268, 60-67. https://doi.org/10.1016/j.desal.2010.09.051

Farghali, M., Andriamanohiarisoamanana, F.J., Ahmed, M.M., Kotb, S., Yamashiro, T., Iwasaki, M., Umetsu, K., 2019. Impacts of iron oxide and titanium dioxide nanoparticles on biogas production: Hydrogen sulfide mitigation, process stability, and prospective challenges. J. Environ. Manage. 240, 160-167. https://doi.org/10.1016/j.jenvman.2019.03.089

Gadhe, A., Sonawane, S.S., Varma, M.N., 2015. Influence of nickel and hematite nanoparticle powder on the production of biohydrogen from complex distillery wastewater in batch fermentation. Int. J. Hydrogen Energy 40, 10734-10743. https://doi.org/10.1016/j.ijhydene.2015.05.198

García, A., Delgado, L., Torà, J.A., Casals, E., González, E., Puntes, V., Font, X., Carrera, J., Sánchez, A., 2012. Effect of cerium dioxide, titanium dioxide, silver, and gold nanoparticles on the activity of microbial communities intended in wastewater treatment. J. Hazard. Mater. 199-200, 64-72. https://doi.org/10.1016/j.jhazmat.2011.10.057

Gautam, D.P., Rahman, S., Fortuna, A.M., Borhan, M.S., Saini-Eidukat, B., Bezbaruah, A.N., 2017. Characterization of zinc oxide nanoparticle $(\mathrm{nZnO})$ alginate beads in reducing gaseous emission from swine manure. Environ. Technol. (United Kingdom) 38, 1061-1074. https://doi.org/10.1080/09593330.2016.1217056

Gitipour, A., Thiel, S.W., Scheckel, K.G., Tolaymat, T., 2016. Anaerobic toxicity of cationic silver nanoparticles. Sci. Total Environ. 557-558, 363-368. https://doi.org/10.1016/j.scitotenv.2016.02.190

Goldstein, A.N., Echer, C.M., Alivisatos, A.P., 1992. Melting in semiconductor nanocrystals. Science (80-. ). 256, 1425-1427. https://doi.org/10.1126/science.256.5062.1425

Gonzalez-Estrella, J., Gallagher, S., Sierra-Alvarez, R., Field, J.A., 2016. Iron sulfide attenuates the methanogenic toxicity of elemental copper and zinc oxide nanoparticles and their soluble metal ion analogs. 
Sci. Total Environ. 548-549, 380-389. https://doi.org/10.1016/j.scitotenv.2016.01.006

Gonzalez-Estrella, J., Puyol, D., Gallagher, S., Sierra-Alvarez, R., Field, J.A., 2015a. Elemental copper nanoparticle toxicity to different trophic groups involved in anaerobic and anoxic wastewater treatment processes. Sci. Total Environ. 512-513, 308-315. https://doi.org/10.1016/j.scitotenv.2015.01.052

Gonzalez-Estrella, J., Puyol, D., Sierra-Alvarez, R., Field, J.A., 2015b. Role of biogenic sulfide in attenuating zinc oxide and copper nanoparticle toxicity to acetoclastic methanogenesis. J. Hazard. Mater. 283, 755763. https://doi.org/10.1016/j.jhazmat.2014.10.030

Gonzalez-Estrella, J., Sierra-Alvarez, R., Field, J.A., 2013. Toxicity assessment of inorganic nanoparticles to acetoclastic and hydrogenotrophic methanogenic activity in anaerobic granular sludge. J. Hazard. Mater. 260, 278-285. https://doi.org/10.1016/j.jhazmat.2013.05.029

Gorby, Y.A., Yanina, S., McLean, J.S., Rosso, K.M., Moyles, D., Dohnalkova, A., Beveridge, T.J., Chang, I.S., Kim, B.H., Kim, K.S., Culley, D.E., Reed, S.B., Romine, M.F., Saffarini, D.A., Hill, E.A., Shi, L., Elias, D.A., Kennedy, D.W., Pinchuk, G., Watanabe, K., Ishii, S., Logan, B., Nealson, K.H., Fredrickson, J.K., 2006. Electrically conductive bacterial nanowires produced by Shewanella oneidensis strain MR-1 and other microorganisms. Proc. Natl. Acad. Sci. U. S. A. 103, 11358-11363. https://doi.org/10.1073/pnas.0604517103

Gustavsson, J., Shakeri Yekta, S., Sundberg, C., Karlsson, A., Ejlertsson, J., Skyllberg, U., Svensson, B.H., 2013. Bioavailability of cobalt and nickel during anaerobic digestion of sulfur-rich stillage for biogas formation. Appl. Energy 112, 473-477. https://doi.org/10.1016/j.apenergy.2013.02.009

Hallenbeck, P.C., 2009. Fermentative hydrogen production: Principles, progress, and prognosis. Int. J. Hydrogen Energy 34, 7379-7389. https://doi.org/10.1016/j.ijhydene.2008.12.080

Han, H., Cui, M., Wei, L., Yang, H., Shen, J., 2011. Enhancement effect of hematite nanoparticles on fermentative hydrogen production. Bioresour. Technol. 102, 7903-7909. https://doi.org/10.1016/j.biortech.2011.05.089

Han, H., Jia, Q., Wei, L., Shen, J., 2014. Influence of $\mathrm{Cu}^{2+}$ concentration on the biohydrogen production of continuous stirred tank reactor. Int. J. Hydrogen Energy 39, 13437-13442. https://doi.org/10.1016/j.ijhydene.2014.04.022

Hariani, P.L., Faizal, M., Ridwan, R., Marsi, M., Setiabudidaya, D., 2013. Synthesis and Properties of $\mathrm{Fe}_{3} \mathrm{O}_{4}$ Nanoparticles by Co-precipitation Method to Removal Procion Dye. Int. J. Environ. Sci. Dev. 4, 336-340. https://doi.org/10.7763/ijesd.2013.v4.366

Hassanein, A., Lansing, S., Tikekar, R., 2019. Impact of metal nanoparticles on biogas production from poultry litter. Bioresour. Technol. 275, 200-206. https://doi.org/10.1016/j.biortech.2018.12.048

Heinlaan, M., Ivask, A., Blinova, I., Dubourguier, H.C., Kahru, A., 2008. Toxicity of nanosized and bulk ZnO, 
$\mathrm{CuO}$ and $\mathrm{TiO}_{2}$ to bacteria Vibrio fischeri and crustaceans Daphnia magna and Thamnocephalus platyurus. Chemosphere 71, 1308-1316. https://doi.org/10.1016/j.chemosphere.2007.11.047

Hsieh, P., Lai, Y., Chen, K., Hung, C., 2016. Explore the possible effect of $\mathrm{TiO}_{2}$ and magnetic hematite nanoparticle addition on biohydrogen production by Clostridium pasteurianum based on gene expression measurements. Int. J. Hydrogen Energy 41, 21685-21691. https://doi.org/10.1016/j.ijhydene.2016.06.197

Huang, H., Chen, Y., Yang, S., Zheng, X., 2019. CuO and ZnO nanoparticles drive the propagation of antibiotic resistance genes during sludge anaerobic digestion: possible role of stimulated signal transduction. Environ. Sci. Nano 6, 528-539. https://doi.org/10.1039/C8EN00370J

Huang, Y., Guo, J., Zhang, C., Hu, Z., 2016. Hydrogen production from the dissolution of nano zero valent iron and its effect on anaerobic digestion. Water Res. 88, 475-480. https://doi.org/10.1016/j.watres.2015.10.028

Jansen, S., Gonzalez-Gil, G., van Leeuwen, H.P., 2007. The impact of Co and Ni speciation on methanogenesis in sulfidic media-Biouptake versus metal dissolution. Enzyme Microb. Technol. 40, 823-830. https://doi.org/10.1016/j.enzmictec.2006.06.019

Jia, T., Wang, Z., Shan, H., Liu, Y., Gong, L., 2017. Effect of nanoscale zero-valent iron on sludge anaerobic digestion. Resour. Conserv. Recycl. 127, 190-195. https://doi.org/10.1016/j.resconrec.2017.09.007

Juntupally, S., Begum, S., Allu, S.K., Nakkasunchi, S., Madugula, M., Anupoju, G.R., 2017. Relative evaluation of micronutrients $(\mathrm{MN})$ and its respective nanoparticles (NPs) as additives for the enhanced methane generation. Bioresour. Technol. 238, 290-295. https://doi.org/10.1016/j.biortech.2017.04.049

Karlsson, H.L., Gustafsson, J., Cronholm, P., Möller, L., 2009. Size-dependent toxicity of metal oxide particlesA comparison between nano- and micrometer size. Toxicol. Lett. 188, 112-118. https://doi.org/10.1016/j.toxlet.2009.03.014

Karvelas, M., Katsoyiannis, A., Samara, C., 2003. Occurrence and fate of heavy metals in the wastewater treatment process. Chemosphere 53, 1201-1210. https://doi.org/10.1016/S0045-6535(03)00591-5

Kato, S., Hashimoto, K., Watanabe, K., 2012. Methanogenesis facilitated by electric syntrophy via ( semi ) conductive iron-oxide minerals 14, 1646-1654. https://doi.org/10.1111/j.1462-2920.2011.02611.x

Kato, S., Watanabe, K., 2010. Ecological and evolutionary interactions in syntrophic methanogenic consortia. Microbes Environ. 25, 145-151. https://doi.org/10.1264/jsme2.ME10122

Khalid, A., Arshad, M., Anjum, M., Mahmood, T., Dawson, L., 2011. The anaerobic digestion of solid organic waste. Waste Manag. 31, 1737-1744. https://doi.org/10.1016/j.wasman.2011.03.021

Khalil, A.M.E., Eljamal, O., Amen, T.W.M., Sugihara, Y., Matsunaga, N., 2017. Optimized nano-scale zerovalent iron supported on treated activated carbon for enhanced nitrate and phosphate removal from water. Chem. Eng. J. 309, 349-365. https://doi.org/10.1016/j.cej.2016.10.080 
Kökdemir Ünşar, E., Perendeci, N.A., 2018. What kind of effects do $\mathrm{Fe}_{2} \mathrm{O}_{3}$ and $\mathrm{Al}_{2} \mathrm{O}_{3}$ nanoparticles have on anaerobic digestion, inhibition or enhancement? Chemosphere 211, 726-735. https://doi.org/10.1016/j.chemosphere.2018.08.014

Lactones, L.N.H., Llamas, I., Keshavan, N., Gonza, J.E., 2004. Use of Sinorhizobium meliloti as an Indicator for Specific Detection of. Society 70, 3715-3723. https://doi.org/10.1128/AEM.70.6.3715

Lee, C., Jee, Y.K., Won, I.L., Nelson, K.L., Yoon, J., Sedlak, D.L., 2008. Bactericidal effect of zero-valent iron nanoparticles on Escherichia coli. Environ. Sci. Technol. 42, 4927-4933. https://doi.org/10.1021/es800408u

Lee, J., Park, K.Y., Cho, J., Kim, J.Y., 2018. Releasing characteristics and fate of heavy metals from phytoremediation crop residues during anaerobic digestion. Chemosphere 191, 520-526. https://doi.org/10.1016/j.chemosphere.2017.10.072

Lei, Y., Wei, L., Liu, T., Xiao, Y., Dang, Y., Sun, D., Holmes, D.E., 2018. Magnetite enhances anaerobic digestion and methanogenesis of fresh leachate from a municipal solid waste incineration plant. Chem. Eng. J. 348, 992-999. https://doi.org/10.1016/j.cej.2018.05.060

Li, H., Cui, F., Liu, Z., Li, D., 2017. Transport, fate, and long-term impacts of metal oxide nanoparticles on the stability of an anaerobic methanogenic system with anaerobic granular sludge. Bioresour. Technol. 234, 448-455. https://doi.org/10.1016/j.biortech.2017.03.027

Li, L.G., Xia, Y., Zhang, T., 2017. Co-occurrence of antibiotic and metal resistance genes revealed in complete genome collection. ISME J. 11, 651-662. https://doi.org/10.1038/ismej.2016.155

Lin, J., Steele, T.W.J., Stuckey, D.C., 2018. The effect of $\mathrm{Fe}_{2} \mathrm{NiO}_{4}$ and $\mathrm{Fe}_{4} \mathrm{NiO}_{4} \mathrm{Zn}$ magnetic nanoparticles on anaerobic digestion activity. Sci. Total Environ. 642, 276-284. https://doi.org/10.1016/j.scitotenv.2018.05.373

Lizama, A.C., Figueiras, C.C., Pedreguera, A.Z., Ruiz Espinoza, J.E., 2019. Enhancing the performance and stability of the anaerobic digestion of sewage sludge by zero valent iron nanoparticles dosage. Bioresour. Technol. 275, 352-359. https://doi.org/10.1016/j.biortech.2018.12.086

Lovestam, G., Rauscher, H., Roebben, G., Kluttgen, B.S., Gibson, N., Putaud, J.-P., Stamm, H., 2010. Considerations on a definition of nanomaterial for regulatory purposes, JRC Reference Reports. https://doi.org/10.2788/98686

Lovley, D.R., 2017. Syntrophy Goes Electric: Direct Interspecies Electron Transfer. Annu. Rev. Microbiol. 71, 643-664. https://doi.org/10.1146/annurev-micro-030117-020420

Luna-delRisco, M., Orupõld, K., Dubourguier, H.C., 2011. Particle-size effect of $\mathrm{CuO}$ and $\mathrm{ZnO}$ on biogas and methane production during anaerobic digestion. J. Hazard. Mater. 189, 603-608. https://doi.org/10.1016/j.jhazmat.2011.02.085 
Ma, J., Gu, J., Wang, X., Peng, H., Wang, Q., Zhang, R., Hu, T., 2019. Effects of nano-zerovalent iron on antibiotic resistance genes during the anaerobic digestion of cattle manure. Bioresour. Technol. 289, 121688. https://doi.org/10.1016/j.biortech.2019.121688

Manitoba Agriculture, F. and R.D., 2015. Properties of Manure 42.

Mao, C., Feng, Y., Wang, X., Ren, G., 2015. Review on research achievements of biogas from anaerobic digestion. Renew. Sustain. Energy Rev. 45, 540-555. https://doi.org/10.1016/j.rser.2015.02.032

Marsalek, B., Jancula, D., Marsalkova, E., Mashlan, M., Safarova, K., Tucek, J., Zboril, R., 2012. Multimodal action and selective toxicity of zerovalent iron nanoparticles against cyanobacteria. Environ. Sci. Technol. 46, 2316-2323. https://doi.org/10.1021/es2031483

Mattioli, A., Bolzonella, D., 2016. Impact of magnetite nanoparticles supplementation on the anaerobic digestion of food wastes : Batch and continuous-flow investigations Impact of Magnetite Nanoparticles Supplementation on the Anaerobic Digestion of Food Wastes: Batch and Continuous- Flow. https://doi.org/10.3303/CET1649001

Mohanraj, S., Anbalagan, K., Rajaguru, P., Pugalenthi, V., 2016. Effects of phytogenic copper nanoparticles on fermentative hydrogen production by Enterobacter cloacae and Clostridium acetobutylicum. Int. J. Hydrogen Energy 41, 10639-10645. https://doi.org/10.1016/j.ijhydene.2016.04.197

Mohanraj, S., Kodhaiyolii, S., 2014. Phytosynthesized iron oxide nanoparticles and ferrous iron on fermentative hydrogen production using Enterobacter cloacae: Evaluation and comparison of the effects. Int. J. Hydrogen Energy 39, 11920-11929. https://doi.org/10.1016/j.ijhydene.2014.06.027

Mohanraj, S., Kodhaiyolii, S., Rengasamy, M., Pugalenthi, V., 2014. Green synthesized iron oxide nanoparticles effect on fermentative hydrogen production by Clostridium acetobutylicum. Appl. Biochem. Biotechnol. 173, 318-331. https://doi.org/10.1007/s12010-014-0843-0

Montemurro, F., Ferri, D., Tittarelli, F., Canali, S., Vitti, 2010. Anaerobic Digestate and On-Farm Compost Application: Effects on. C Compost Sci. Util. Summer 18.

Mostafaii, G., Chimehi, E., Gilasi, H.R., Iranshahi, L., 2017. Investigation of zinc oxide nanoparticles effects on removal of total coliform bacteria in activated sludge process effluent of municipal wastewater. J. Environ. Sci. Technol. 10, 49-55. https://doi.org/10.3923/jest.2017.49.55

$\mathrm{Mu}, \mathrm{H}$., Chen, Y., 2011. Long-term effect of $\mathrm{ZnO}$ nanoparticles on waste activated sludge anaerobic digestion. Water Res. 45, 5612-5620. https://doi.org/10.1016/j.watres.2011.08.022

$\mathrm{Mu}, \mathrm{H}$., Chen, Y., Xiao, N., 2011. Effects of metal oxide nanoparticles $\left(\mathrm{TiO}_{2}, \mathrm{Al}_{2} \mathrm{O}_{3}, \mathrm{SiO}_{2}\right.$ and $\left.\mathrm{ZnO}\right)$ on waste activated sludge anaerobic digestion. Bioresour. Technol. 102, 10305-10311. https://doi.org/10.1016/j.biortech.2011.08.100

Mu, H., Zheng, X., Chen, Y., Chen, H., Liu, K., 2012. Response of anaerobic granular sludge to a shock load 
of zinc oxide nanoparticles during biological wastewater treatment. Environ. Sci. Technol. 46, 5997-6003. https://doi.org/10.1021/es300616a

Nasr, M., Tawfik, A., Ookawara, S., Suzuki, M., 2013. Hydrogen prodcution from starch wastewater using anaerobic sludge immobilized on maghemite nanoparticle 5-7.

Nguyen, D., Visvanathan, C., Jacob, P., Jegatheesan, V., 2015. Effects of nano cerium (IV) oxide and zinc oxide particles on biogas production. Int. Biodeterior. Biodegrad. 102, 165-171. https://doi.org/10.1016/j.ibiod.2015.02.014

Ni, B.J., Huang, Q.S., Wang, C., Ni, T.Y., Sun, J., Wei, W., 2019. Competitive adsorption of heavy metals in aqueous solution onto biochar derived from anaerobically digested sludge. Chemosphere 219, 351-357. https://doi.org/10.1016/j.chemosphere.2018.12.053

Osuna, M.B., Iza, J., Zandvoort, M., 1997. Essential metal depletion in an anaerobic reactor. Water Sci. Technol. $48,1-8$.

Otero-González, L., Field, J.A., Sierra-Alvarez, R., 2014. Fate and long-term inhibitory impact of ZnO nanoparticles during high-rate anaerobic wastewater treatment. J. Environ. Manage. 135, 110-117. https://doi.org/10.1016/j.jenvman.2014.01.025

Pan, X., Lv, N., Li, C., Ning, J., Wang, T., Wang, R., 2019. Impact of nano zero valent iron on tetracycline degradation and microbial community succession during anaerobic digestion 359, 662-671. https://doi.org/10.1016/j.cej.2018.11.135

Pruden, A., Pei, R., Storteboom, H., Carlson, K.H., 2006. Antibiotic resistance genes as emerging contaminants: Studies in northern Colorado. Environ. Sci. Technol. 40, 7445-7450. https://doi.org/10.1021/es0604131

Pugazhendhi, A., Shobana, S., Nguyen, D.D., Banu, J.R., Sivagurunathan, P., Chang, S.W., Ponnusamy, V.K., Kumar, G., 2019. Application of nanotechnology (nanoparticles) in dark fermentative hydrogen production. Int. J. Hydrogen Energy 44, 1431-1440. https://doi.org/10.1016/j.ijhydene.2018.11.114

Qiang, H., Niu, Q., Chi, Y., Li, Y., 2013. Trace metals requirements for continuous thermophilic methane fermentation of high-solid food waste. Chem. Eng. J. 222, 330-336. https://doi.org/10.1016/j.cej.2013.02.076

Qin, H., Lu, K., Strong, P.J., Xu, Q., Wu, Q., Xu, Z., Xu, J., Wang, H., 2015. Long-term fertilizer application effects on the soil, root arbuscular mycorrhizal fungi and community composition in rotation agriculture. Appl. Soil Ecol. 89, 35-43. https://doi.org/10.1016/j.apsoil.2015.01.008

Reguera, G., McCarthy, K.D., Mehta, T., Nicoll, J.S., Tuominen, M.T., Lovley, D.R., 2005. Extracellular electron transfer via microbial nanowires. Nature 435, 1098-1101. https://doi.org/10.1038/nature03661

Rehl, T., Müller, J., 2011. Life cycle assessment of biogas digestate processing technologies. Resour. Conserv. Recycl. 56, 92-104. https://doi.org/10.1016/j.resconrec.2011.08.007 
Romero-güiza, M.S., Vila, J., Mata-alvarez, J., Chimenos, J.M., Astals, S., 2016. The role of additives on anaerobic digestion : A review 58, 1486-1499. https://doi.org/10.1016/j.rser.2015.12.094

Rudnick, H., Hendrich, S., Pilatus, U., Blotevogel, K.H., 1990. Phosphate accumulation and the occurrence of polyphosphates and cyclic 2,3-diphosphoglycerate in Methanosarcina frisia. Arch. Microbiol. 154, 584588. https://doi.org/10.1007/BF00248840

Sakinah, N., Mohamed, P., Wu, S., 2017. Influence of iron (II) oxide nanoparticle on biohydrogen production in thermophilic mixed fermentation. Int. J. Hydrogen Energy 42, 27482-27493. https://doi.org/10.1016/j.ijhydene.2017.05.224

Sawatdeenarunat, C., Surendra, K.C., Takara, D., Oechsner, H., Khanal, S.K., 2015. Anaerobic digestion of lignocellulosic biomass: Challenges and opportunities. Bioresour. Technol. 178, 178-186. https://doi.org/10.1016/j.biortech.2014.09.103

Seadi, T. Al, Rutz, D., Prassl, H., Kottner, M., Finsterwalder, T., Volk, S., Janssen, R., 2008. Biogas handbook. Applied Sciences and Technology. https://doi.org/10.1007/978-981-10-4130-3_2

Song, H.S., Park, M.G., Kwon, S.J., Yi, K.B., Croiset, E., Chen, Z., Nam, S.C., 2013. Hydrogen sulfide adsorption on nano-sized zinc oxide/reduced graphite oxide composite at ambient condition. Appl. Surf. Sci. 276, 646-652. https://doi.org/10.1016/j.apsusc.2013.03.147

Sreekanth, K.M., Sahu, D., 2015. Effect of iron oxide nanoparticle in bio digestion of a portable food-waste digester. Synthesis (Stuttg). 7, 353-359.

St-Pierre, B., Wright, A.D.G., 2017. Implications from distinct sulfate-reducing bacteria populations between cattle manure and digestate in the elucidation of $\mathrm{H}_{2} \mathrm{~S}$ production during anaerobic digestion of animal slurry. Appl. Microbiol. Biotechnol. 101, 5543-5556. https://doi.org/10.1007/s00253-017-8261-1

Su, L., Shi, X., Guo, G., Zhao, A., Zhao, Y., 2013. Stabilization of sewage sludge in the presence of nanoscale zero-valent iron (nZVI): Abatement of odor and improvement of biogas production. J. Mater. Cycles Waste Manag. 15, 461-468. https://doi.org/10.1007/s10163-013-0150-9

Su, L., Zhen, G., Zhang, L., Zhao, Y., 2015. The use of the core-shell structure of zero-valents iron nanoparticles (NZVI) for long-term removal of sulphide in sludge during anaerobic digestion 2013-2021. https://doi.org/10.1039/c5em00470e

Suanon, F., Sun, Q., Mama, D., Li, J., Dimon, B., Yu, C.P., 2016. Effect of nanoscale zero-valent iron and magnetite $\left(\mathrm{Fe}_{3} \mathrm{O}_{4}\right)$ on the fate of metals during anaerobic digestion of sludge. Water Res. 88, 897-903. https://doi.org/10.1016/j.watres.2015.11.014

Taherdanak, M., Zilouei, H., Karimi, K., 2015. Investigating the effects of iron and nickel nanoparticles on dark hydrogen fermentation from starch using central composite design. Int. J. Hydrogen Energy 40, 1295612963. https://doi.org/10.1016/j.ijhydene.2015.08.004 
Talapin, D. V., Rogach, A.L., Haase, M., Weller, H., 2001. Evolution of an ensemble of nanoparticles in a colloidal solution: Theoretical study. J. Phys. Chem. B 105, 12278-12285. https://doi.org/10.1021/jp012229m

Tan, C.H., Koh, K.S., Xie, C., Tay, M., Zhou, Y., Williams, R., Ng, W.J., Rice, S.A., Kjelleberg, S., 2014. The role of quorum sensing signalling in EPS production and the assembly of a sludge community into aerobic granules. ISME J. 8, 1186-1197. https://doi.org/10.1038/ismej.2013.240

Tang, S.C.N., Lo, I.M.C., 2013. Magnetic nanoparticles: Essential factors for sustainable environmental applications. Water Res. 47, 2613-2632. https://doi.org/10.1016/j.watres.2013.02.039

Thauer, R.K., Kaster, A.K., Seedorf, H., Buckel, W., Hedderich, R., 2008. Methanogenic archaea: Ecologically relevant differences in energy conservation. Nat. Rev. Microbiol. 6, 579-591. https://doi.org/10.1038/nrmicro1931

Tong, T., Fang, K., Thomas, S.A., Kelly, J.J., Gray, K.A., Gaillard, J.F., 2014. Chemical interactions between nano- $\mathrm{ZnO}$ and nano- $\mathrm{TiO}_{2}$ in a natural aqueous medium. Environ. Sci. Technol. 48, 7924-7932. https://doi.org/10.1021/es501168p

Trifunović, D., Schuchmann, K., Müller, V., 2016. Ethylene glycol metabolism in the acetogen Acetobacterium woodii. J. Bacteriol. 198, 1058-1065. https://doi.org/10.1128/JB.00942-15

Ünşar, E.K., Çiłgin, A.S., Erdem, A., Perendeci, N.A., 2016. Long and short term impacts of CuO, $\mathrm{Ag}$ and $\mathrm{CeO}_{2}$ nanoparticles on anaerobic digestion of municipal waste activated sludge. Environ. Sci. Process. Impacts 18, 277-288. https://doi.org/10.1039/c5em00466g

Valle, A., Bailey, M.J., Whiteley, A.S., Manefield, M., 2004. N-acyl-L-homoserine lactones (AHLs) affect microbial community composition and function in activated sludge. Environ. Microbiol. 6, 424-433. https://doi.org/10.1111/j.1462-2920.2004.00581.x

Von Wintersdorff, C.J.H., Penders, J., Van Niekerk, J.M., Mills, N.D., Majumder, S., Van Alphen, L.B., Savelkoul, P.H.M., Wolffs, P.F.G., 2016. Dissemination of antimicrobial resistance in microbial ecosystems through horizontal gene transfer. Front. Microbiol. 7, 1-10. https://doi.org/10.3389/fmicb.2016.00173

Wang, S., Li, Z., Gao, M., She, Z., Ma, B., Guo, L., Zheng, D., Zhao, Y., Jin, C., Wang, X., Gao, F., 2017. Long-term effects of cupric oxide nanoparticles $(\mathrm{CuO} \mathrm{NPs})$ on the performance, microbial community and enzymatic activity of activated sludge in a sequencing batch reactor. J. Environ. Manage. 187, 330-339. https://doi.org/10.1016/j.jenvman.2016.11.071

Wang, T., Zhang, D., Dai, L., Chen, Y., Dai, X., 2016. Effects of metal nanoparticles on methane production from waste-activated sludge and microorganism community shift in anaerobic granular sludge. Sci. Rep. 6, 1-10. https://doi.org/10.1038/srep25857 
Wang, W., Zhou, M., Mao, Q., Yue, J., Wang, X., 2010. Novel NaY zeolite-supported nanoscale zero-valent iron as an efficient heterogeneous Fenton catalyst. Catal. Commun. 11, 937-941. https://doi.org/10.1016/j.catcom.2010.04.004

Wang, Y., Wang, D., Fang, H., 2018a. Comparison of enhancement of anaerobic nano-zero valent iron and zero valent iron $\uparrow 27181-27190$. https://doi.org/10.1039/c8ra05369c

Wang, Y., Wang, D., Fang, H., 2018b. Comparison of enhancement of anaerobic digestion of waste activated sludge through adding nano-zero valent iron and zero valent iron. RSC Adv. 8, 27181-27190. https://doi.org/10.1039/c8ra05369c

Weber, K.A., Achenbach, L.A., Coates, J.D., 2006. Microorganisms pumping iron: Anaerobic microbial iron oxidation and reduction. Nat. Rev. Microbiol. 4, 752-764. https://doi.org/10.1038/nrmicro1490

Wu, D., Shen, Y., Ding, A., Mahmood, Q., Liu, S., Tu, Q., 2013. Effects of nanoscale zero-valent iron particles on biological nitrogen and phosphorus removal and microorganisms in activated sludge. J. Hazard. Mater. 262, 649-655. https://doi.org/10.1016/j.jhazmat.2013.09.038

Xia, T., Kovochich, M., Liong, M., Mädler, L., Gilbert, B., Shi, H., Yeh, J.I., Zink, J.I., Nel, A.E., 2008. Comparison of the mechanism of toxicity of zinc oxide and cerium oxide nanoparticles based on dissolution and oxidative stress properties. ACS Nano 2, 2121-2134. https://doi.org/10.1021/nn800511k

Yamada, C., Kato, S., Ueno, Y., Ishii, M., Igarashi, Y., 2015. Conductive iron oxides accelerate thermophilic methanogenesis from acetate and propionate. J. Biosci. Bioeng. 119, 678-682. https://doi.org/10.1016/j.jbiosc.2014.11.001

Yang, Y., Chen, Q., Wall, J.D., Hu, Z., 2012a. Potential nanosilver impact on anaerobic digestion at moderate silver concentrations. Water Res. 46, 1176-1184. https://doi.org/10.1016/j.watres.2011.12.024

Yang, Y., Xu, M., Wall, J.D., Hu, Z., 2012b. Nanosilver impact on methanogenesis and biogas production from municipal solid waste. Waste Manag. 32, 816-825. https://doi.org/10.1016/j.wasman.2012.01.009

Yang, Y., Zhang, C., Hu, Z., 2013. Impact of metallic and metal oxide nanoparticles on wastewater treatment and anaerobic digestion. Environ. Sci. Process. Impacts 15, 39-48. https://doi.org/10.1039/c2em30655g

Yang, Z., Xu, X., Guo, R., Fan, X., Zhao, X., 2015. Accelerated methanogenesis from effluents of hydrogenproducing stage in anaerobic digestion by mixed cultures enriched with acetate and nano-sized magnetite particles. Bioresour. Technol. 190, 132-139. https://doi.org/10.1016/j.biortech.2015.04.057

Yekta, S.S., Skyllberg, U., Danielsson, Å., Björn, A., Svensson, B.H., 2017. Chemical speciation of sulfur and metals in biogas reactors - Implications for cobalt and nickel bio-uptake processes. J. Hazard. Mater. 324, 110-116. https://doi.org/10.1016/j.jhazmat.2015.12.058

Yu, B., Huang, X., Zhang, D., Lou, Z., Yuan, H., Zhu, N., 2016. Response of sludge fermentation liquid and microbial community to nano zero-valent iron exposure in a mesophilic anaerobic digestion system. RSC 
Adv. 6, 24236-24244. https://doi.org/10.1039/c6ra02591a

Zaidi, A.A., Feng, R., Malik, A., Khan, S.Z., Shi, Y., Bhutta, A.J., Shah, A.H., 2019. Combining microwave pretreatment with iron oxide nanoparticles enhanced biogas and hydrogen yield from green algae. Processes 7. https://doi.org/10.3390/pr7010024

Zaidi, A.A., Ruizhe, F., Shi, Y., Khan, S.Z., 2018. Nanoparticles augmentation on biogas yield from microalgal biomass anaerobic digestion. Int. J. Hydrogen Energy 43, 14202-14213. https://doi.org/10.1016/j.ijhydene.2018.05.132

Zayed, G., Winter, J., 2000. Inhibition of methane production from whey by heavy metals - Protective effect of sulfide. Appl. Microbiol. Biotechnol. 53, 726-731. https://doi.org/10.1007/s002530000336

Zhang, J., Wang, Z., Lu, T., Liu, J., Wang, Y., Shen, P., Wei, Y., 2019. Response and mechanisms of the performance and fate of antibiotic resistance genes to nano-magnetite during anaerobic digestion of swine manure. J. Hazard. Mater. 366, 192-201. https://doi.org/10.1016/j.jhazmat.2018.11.106

Zhang, J., Zhao, W., Zhang, H., Wang, Z., Fan, C., Zang, L., 2018. Recent achievements in enhancing anaerobic digestion with carbon- based functional materials. Bioresour. Technol. 266, 555-567. https://doi.org/10.1016/j.biortech.2018.07.076

Zhang, L., He, X., Zhang, Z., Cang, D., Nwe, K.A., Zheng, L., Li, Z., Cheng, S., 2017. Evaluating the influences of $\mathrm{ZnO}$ engineering nanomaterials on VFA accumulation in sludge anaerobic digestion. Biochem. Eng. J. 125, 206-211. https://doi.org/10.1016/j.bej.2017.05.008

Zhang, L., Zhang, Z., He, X., Zheng, L., Cheng, S., Li, Z., 2019. Diminished inhibitory impact of ZnO nanoparticles on anaerobic fermentation by the presence of $\mathrm{TiO}_{2}$ nanoparticles: Phenomenon and mechanism. Sci. Total Environ. 647, 313-322. https://doi.org/10.1016/j.scitotenv.2018.07.468

Zhang, Y., Shen, J., 2007. Enhancement effect of gold nanoparticles on biohydrogen production from artificial wastewater. Int. J. Hydrogen Energy 32, 17-23. https://doi.org/10.1016/j.ijhydene.2006.06.004

Zhao, L., Ji, Y., Sun, P., Deng, J., Wang, H., Yang, Y., 2019. Effects of individual and combined zinc oxide nanoparticle, norfloxacin, and sulfamethazine contamination on sludge anaerobic digestion. Bioresour. Technol. 273, 454-461. https://doi.org/10.1016/j.biortech.2018.11.049

Zhao, W., Zhang, Y., Du, B., Wei, D., Wei, Q., Zhao, Y., 2013. Enhancement effect of silver nanoparticles on fermentative biohydrogen production using mixed bacteria. Bioresour. Technol. 142, 240-245. https://doi.org/10.1016/j.biortech.2013.05.042

Zhen, G., Lu, X., Kato, H., Zhao, Y., Li, Y.Y., 2017. Overview of pretreatment strategies for enhancing sewage sludge disintegration and subsequent anaerobic digestion: Current advances, full-scale application and future perspectives. Renew. Sustain. Energy Rev. 69, 559-577. https://doi.org/10.1016/j.rser.2016.11.187

Zhen, G., Lu, X., Li, Y., Liu, Y., Zhao, Y., 2015. Influence of zero valent scrap iron ( ZVSI ) supply on methane 
production from waste activated sludge. Chem. Eng. J. 263, 461-470. https://doi.org/10.1016/j.cej.2014.11.003

Zheng, L., Zhang, Z., Tian, L., Zhang, L., Cheng, S., Li, Z., Cang, D., 2019. Mechanistic investigation of toxicological change in $\mathrm{ZnO}$ and $\mathrm{TiO}_{2}$ multi-nanomaterial systems during anaerobic digestion and the microorganism response. Biochem. Eng. J. 147, 62-71. https://doi.org/10.1016/j.bej.2019.03.017

Zheng, X., Wu, L., Chen, Y., Su, Y., Wan, R., Liu, K., Huang, H., 2015. Effects of titanium dioxide and zinc oxide nanoparticles on methane production from anaerobic co-digestion of primary and excess sludge. J. Environ. Sci. Heal. - Part A Toxic/Hazardous Subst. Environ. Eng. 50, 913-921. https://doi.org/10.1080/10934529.2015.1030279

Zheng, X., Yang, L., Shen, Q., Zhou, C., 2019. Evaluation of Zinc Oxide Nanoparticles-Induced Effects on Nitrogen and Phosphorus Removal from Real and Synthetic Municipal Wastewater. Ind. Eng. Chem. Res. 58, 7929-7936. https://doi.org/10.1021/acs.iecr.9b00641

Zhou, S., Xu, J., Yang, G., Zhuang, L., 2014. Methanogenesis affected by the co-occurrence of iron(III) oxides and humic substances. FEMS Microbiol. Ecol. 88, 107-120. https://doi.org/10.1111/1574-6941.12274

Zhu, K., Zhang, L., Mu, L., Ma, J., Wang, X., Li, C., Cui, Y., 2019. Antagonistic effect of zinc oxide nanoparticle and surfactant on anaerobic digestion: Focusing on the microbial community changes and interactive mechanism. https://doi.org/10.1016/j.biortech.2019.122382 


\section{Figures}

Impact of Metallic Nanoparticles on Anaerobic Digestion: a Systematic Review

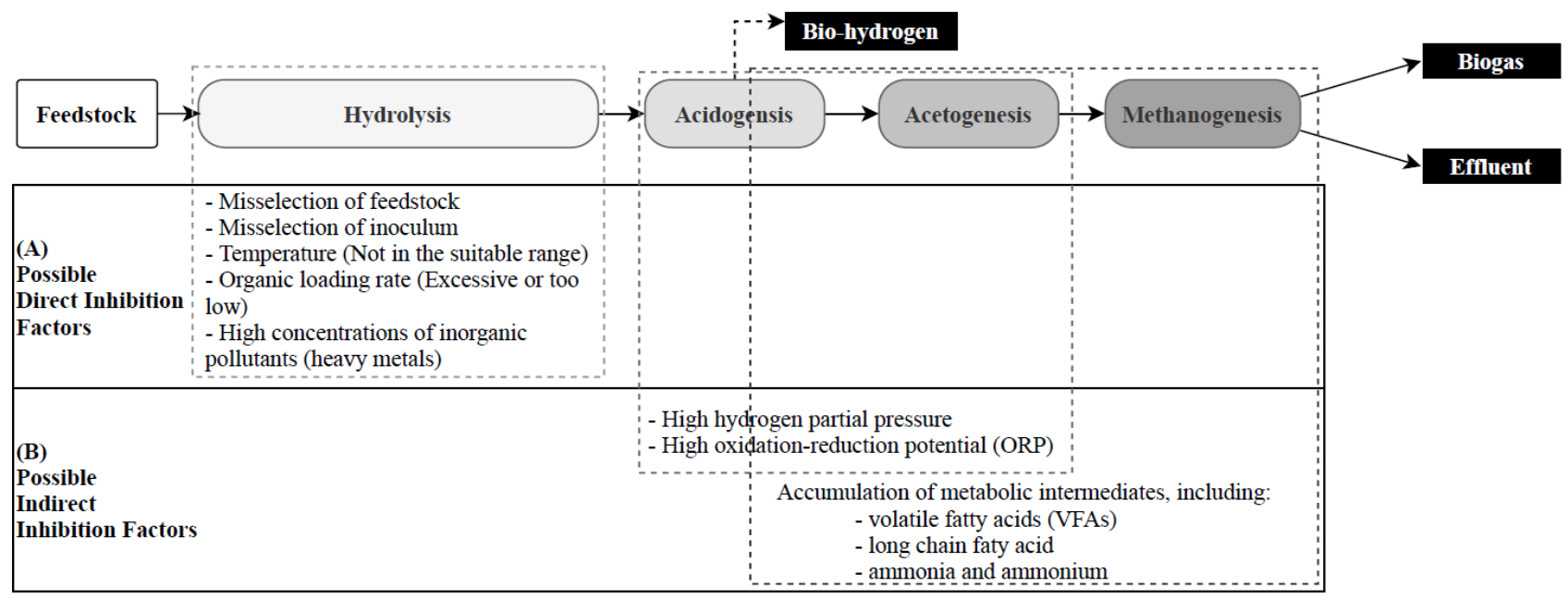

Fig. 1. Phases of AD process with possible inhibition factors and limitations of outputs. 


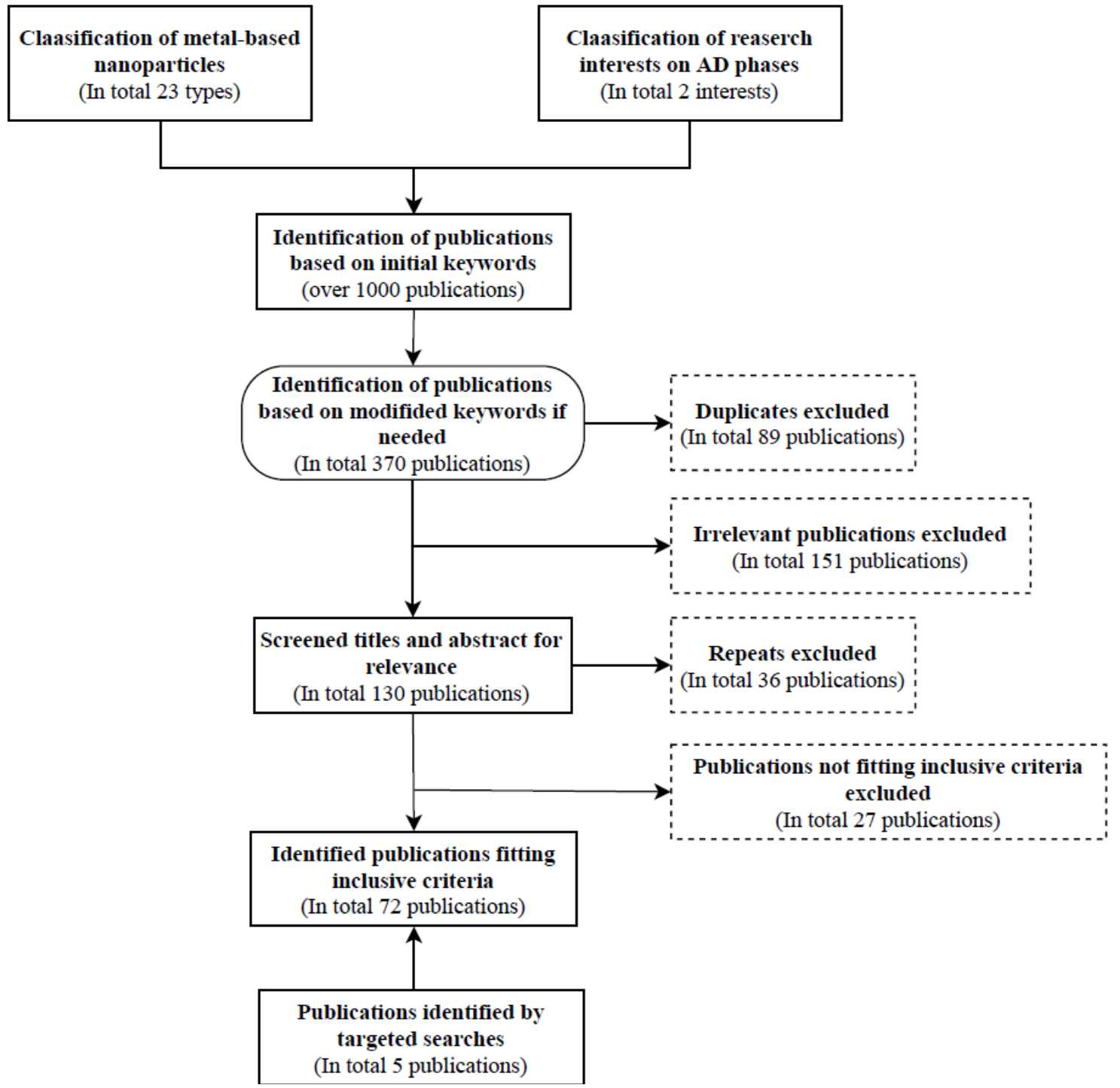

Fig. 2. The process of literature searches of this review. 


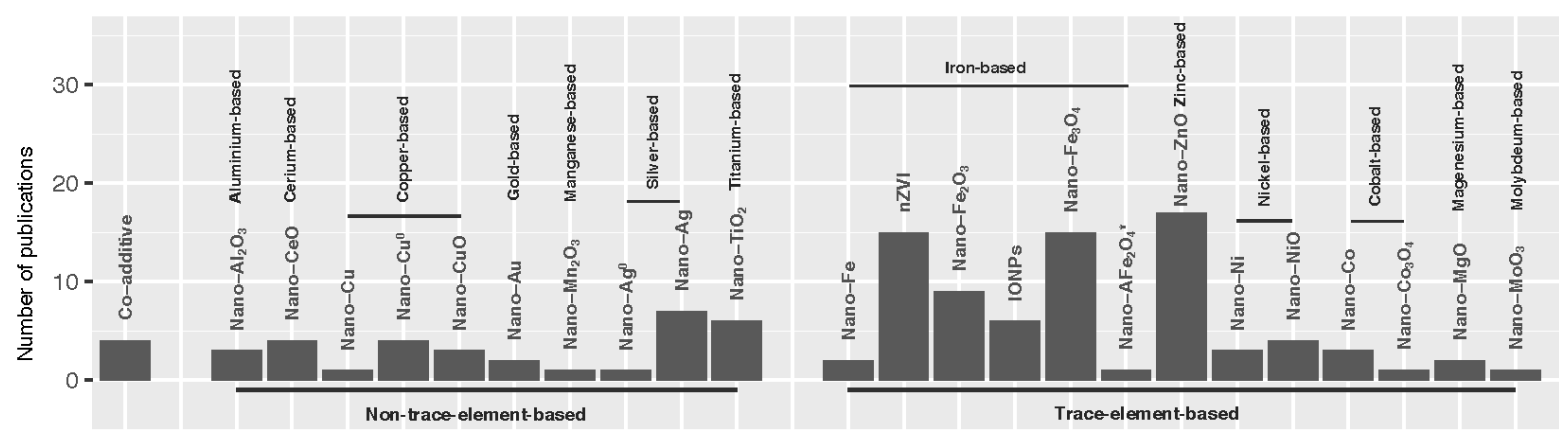

Fig. 3. Categorization and counts of publications in this study. 


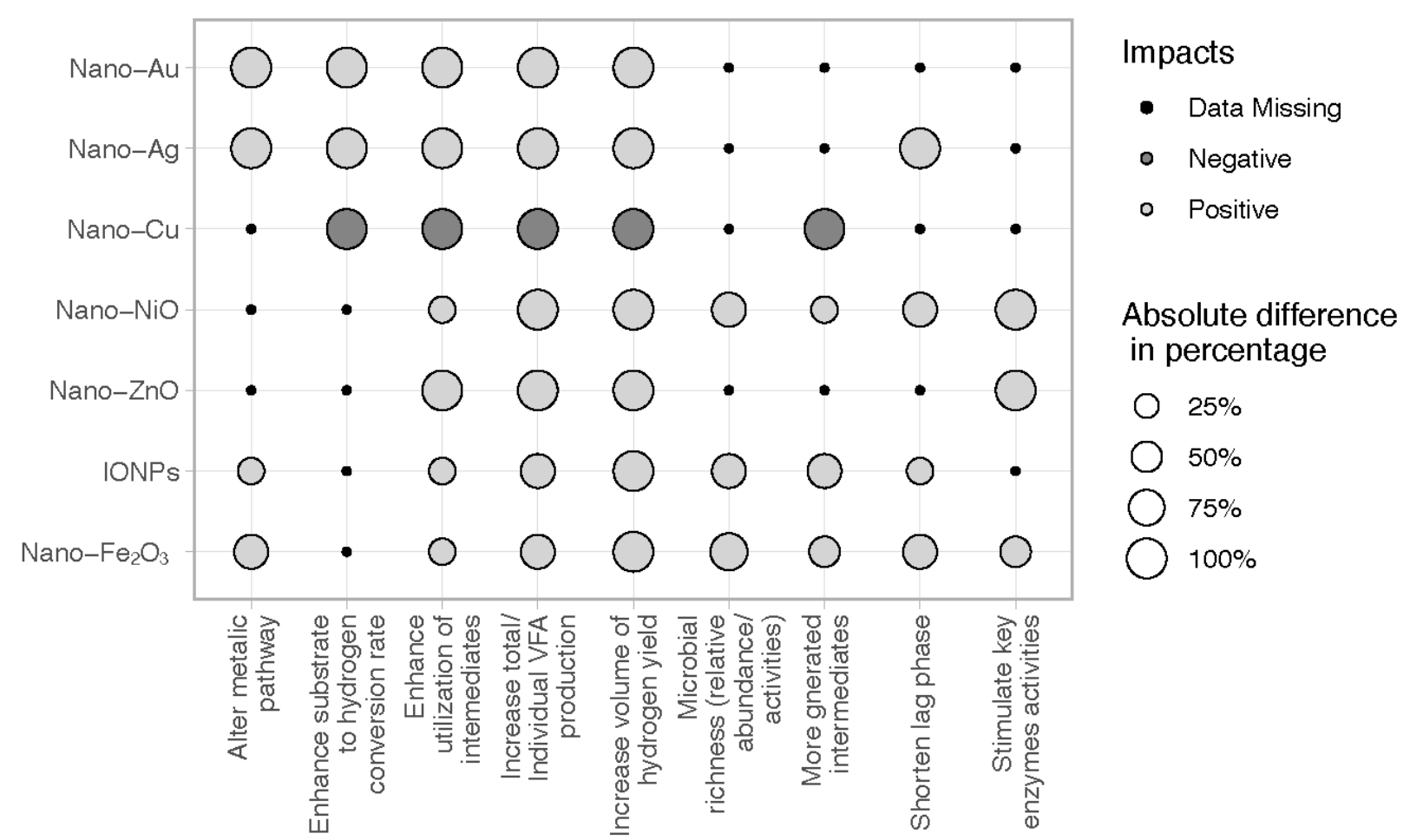

Fig. 4. Qualitative analysis for metallic nanoparticles impact on $\mathrm{AD}$ fermentation phase.

*: Only one publication was included in this review. 


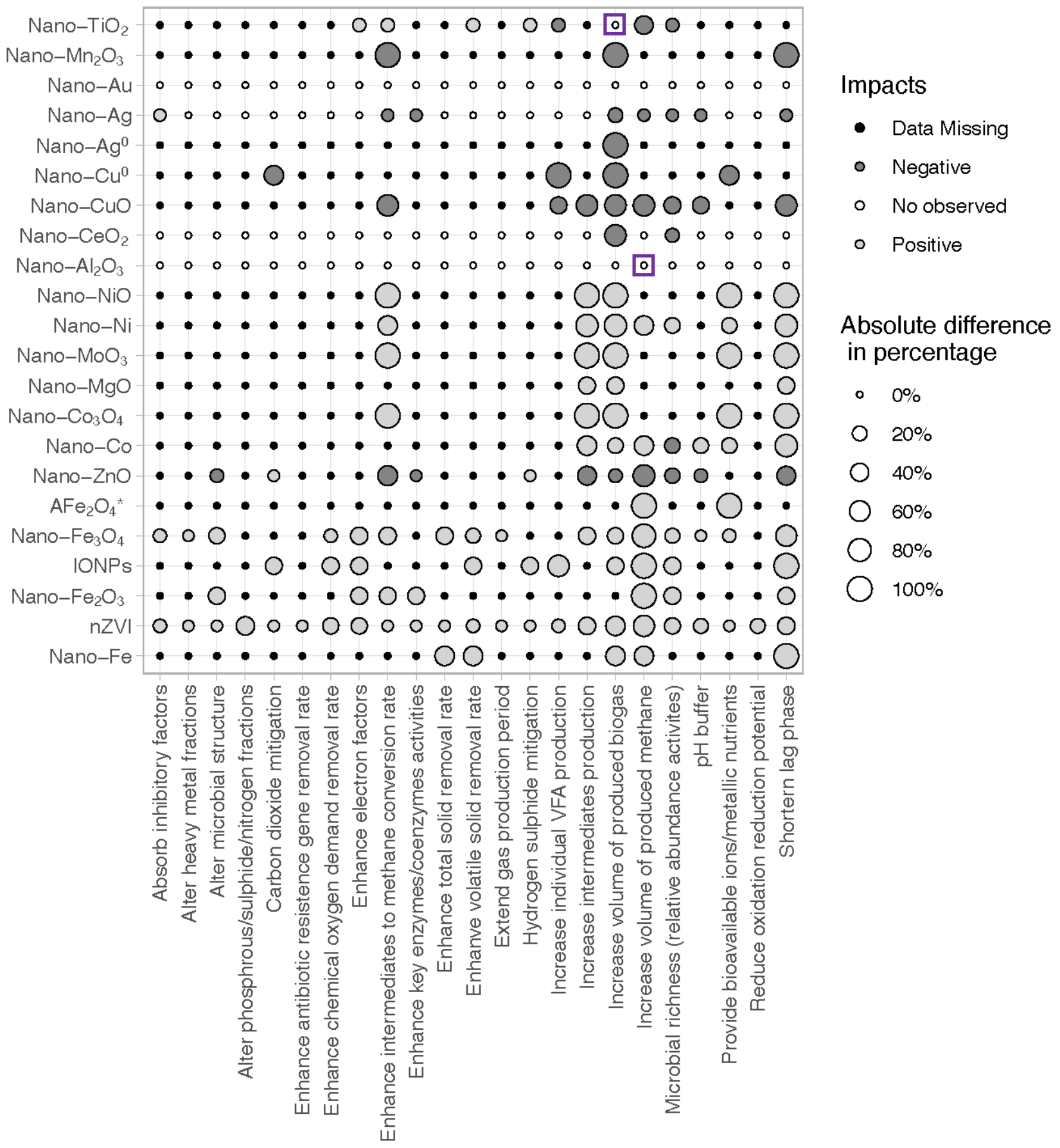

Fig. 5. Qualitative analysis of metallic nanoparticles impact on methane-production and overall AD processes.

*: A stands for a types of metal, such as nickel and zinc. 
Reported tolerate concentrations for $\mathrm{AD}$ fermentation phase, $\mathrm{mg} / \mathrm{L}$

Reported tolerate concentrations for methane-production and overall $\mathrm{AD}$ phase, $\mathrm{mg} / \mathrm{L}$

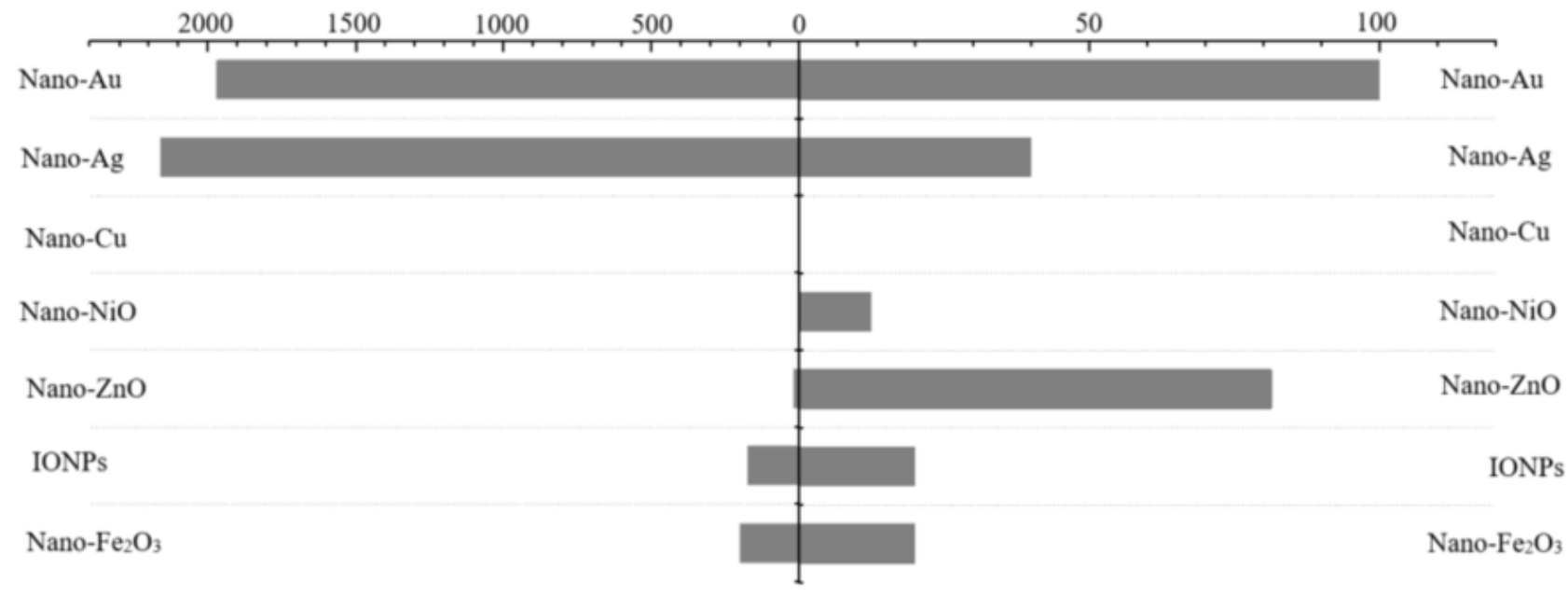

Fig. 6. Comparison of reported tolerate concentrations of metallic nanoparticles for both research interests. 
Tables

\section{Impact of Metallic Nanoparticles on Anaerobic Digestion: a Systematic Review}

Table 1. Reported tolerate concentrations of selected metallic nanoparticles on the AD fermentation phase.

\begin{tabular}{|c|c|c|c|c|}
\hline $\begin{array}{l}\text { Types of } \\
\text { nanoparticles }\end{array}$ & $\begin{array}{l}\text { Size of the } \\
\text { nanoparticles, nm }\end{array}$ & $\begin{array}{l}\text { Highest reported } \\
\text { concentrations }\end{array}$ & Notes & Reference \\
\hline $\mathrm{Nano}-\mathrm{Fe}_{2} \mathrm{O}_{3}$ & $33, \sim 50^{\mathrm{a}}$ and $<100$ & $200 \mathrm{mg} / \mathrm{L}$ & Best performance & $\begin{array}{l}\text { (Gadhe et al., 2015), (Han et al., } \\
\text { 2011) }\end{array}$ \\
\hline IONPs & $\sim 50$ & $175 \mathrm{mg} / \mathrm{L}$ & Best performance & $\begin{array}{l}\text { (Mohanraj and Kodhaiyolii, 2014), } \\
\text { (Mohanraj et al., 2014) }^{\mathrm{b}}\end{array}$ \\
\hline Nano-ZnO & $<100$ & $10 \mathrm{mg} / \mathrm{g} \mathrm{VS}$ & $\begin{array}{l}\text { No adverse } \\
\text { impacts }\end{array}$ & (Elreedy et al., 2019) \\
\hline Nano-NiO & 23 & $5 \mathrm{mg} / \mathrm{L}$ & $\begin{array}{l}\text { No adverse } \\
\text { impacts }\end{array}$ & (Gadhe et al., 2015) \\
\hline Nano- $\mathrm{Cu}$ & $\sim 100^{\mathrm{a}}$ & $0 \mathrm{mg} / \mathrm{L}^{\mathrm{c}}$ & $\begin{array}{l}\text { Inhibit AD } \\
\text { fermentation }\end{array}$ & (Mohanraj et al., 2016) \\
\hline Nano-Ag & $\sim 15^{\mathrm{a}}$ & $20 \mathrm{nM}$ & Best performance & (Zhao et al., 2013) \\
\hline Nano-Au & 5 & $10 \mathrm{nM}$ & Best performance & (Zhang and Shen, 2007) \\
\hline \multicolumn{5}{|c|}{$\begin{array}{l}\text { a: Approximate. } \\
\text { b: The reason for choosing this concentration as up limit is due to the selection of feedstock (two studies applied with similar } \\
\text { selection) and size range of the nanoparticle (similar choice with the selection of nano- } \mathrm{Fe}_{2} \mathrm{O}_{3} \text { ). } \\
\text { c. }\end{array}$} \\
\hline
\end{tabular}


Table 2. Reported tolerate concentrations of selected metallic nanoparticles on the methane-production stage and overall AD process.

\begin{tabular}{|c|c|c|c|c|}
\hline $\begin{array}{l}\text { Types of } \\
\text { nanoparticles }\end{array}$ & $\begin{array}{l}\text { Size of the } \\
\text { nanoparticles, nm }\end{array}$ & $\begin{array}{l}\text { Highest reported } \\
\text { concentrations }\end{array}$ & Notes & Reference \\
\hline Nano-Fe & $\sim 10^{\mathrm{a}}$ & $20 \mathrm{mg} / \mathrm{L}$ & Best performance & (Abdelsalam et al., 2016a) \\
\hline nZVI & 100 & $0.5 \mathrm{~g} / \mathrm{g} \mathrm{VS}$ & Best performance & (Pan et al., 2019) \\
\hline Nano- $\mathrm{Fe}_{2} \mathrm{O}_{3}$ & $<30$ & $100 \mathrm{mg} / \mathrm{g}$ TSS & Best performance & (Wang et al., 2016) \\
\hline IONPs & $\sim 50^{\mathrm{a}}$ & $20 \mathrm{mg} / \mathrm{L}$ & Best performance & (Sreekanth and Sahu, 2015) \\
\hline $\mathrm{Nano}_{-} \mathrm{Fe}_{3} \mathrm{O}_{4}$ & $\sim 10^{\mathrm{a}}$ & $100 \mathrm{mg} / \mathrm{L}$ & Best performance & (Arbiol et al., 2014) \\
\hline $\mathrm{Nano}_{-} \mathrm{AFe}_{2} \mathrm{NiO}_{4}$ & $\sim 50^{\mathrm{a}}$ & $400 \mathrm{mg} / \mathrm{L}$ & $\begin{array}{l}\text { Only one } \\
\text { publication }\end{array}$ & (Lin et al., 2018) \\
\hline Nano-ZnO & $\sim 30^{\mathrm{a}}$ & $1 \mathrm{mM}$ & $\begin{array}{l}\text { Limited adverse } \\
\text { impacts }\end{array}$ & (Zhu et al., n.d.) \\
\hline Nano-Co & $\sim 30^{\mathrm{a}}$ & $1 \mathrm{mg} / \mathrm{L}$ & Best performance & (Abdelsalam et al., 2016b) \\
\hline $\mathrm{Nano}-\mathrm{Co}_{3} \mathrm{O}_{4}$ & $\sim 30^{\mathrm{a}}$ & $12.5 \mathrm{mg} / \mathrm{L}$ & $\begin{array}{l}\text { Only one } \\
\text { publication }\end{array}$ & (Juntupally et al., 2017) \\
\hline Nano-MgO & $<100^{\mathrm{b}}$ & $1 \mathrm{mg} / \mathrm{L} \mathrm{TSS}^{\mathrm{b}}$ & No adverse impacts & (Wang et al., 2016) \\
\hline $\mathrm{Nano}-\mathrm{MoO}_{3}$ & 15 & $12.5 \mathrm{mg} / \mathrm{L}$ & $\begin{array}{l}\text { Only one } \\
\text { publication }\end{array}$ & (Juntupally et al., 2017) \\
\hline Nano-Ni & $\sim 20^{\mathrm{a}}$ & $2 \mathrm{mg} / \mathrm{L}$ & Best performance & (Abdelsalam et al., 2016b) \\
\hline Nano-NiO & $\sim 20^{\mathrm{a}}$ & $12.5 \mathrm{mg} / \mathrm{L}$ & $\begin{array}{l}\text { Only one } \\
\text { publication }\end{array}$ & (Juntupally et al., 2017) \\
\hline $\mathrm{Nano}-\mathrm{Al}_{2} \mathrm{O}_{3}$ & $<50$ & $1500 \mathrm{mg} / \mathrm{L}$ & $\begin{array}{l}\text { Limited adverse } \\
\text { impacts }\end{array}$ & $\begin{array}{l}\text { (Gonzalez-Estrella et al., } \\
\text { 2013) }\end{array}$ \\
\hline Nano- $\mathrm{CeO}_{2}$ & $\sim 10^{\mathrm{a}}$ & $0.16 \mathrm{mg} / \mathrm{mL}$ & $\begin{array}{l}\text { Limited adverse } \\
\text { impacts }\end{array}$ & (García et al., 2012) \\
\hline Nano-CuO & 30 & $15 \mathrm{mg} / \mathrm{L}$ & $\begin{array}{l}\text { Limited adverse } \\
\text { impacts }\end{array}$ & (Luna-delRisco et al., 2011) \\
\hline Nano- $\mathrm{Cu}^{0}$ & $\sim 50^{\mathrm{a}}$ & $0.382 \mathrm{mM} \mathrm{Cu}$ & $\begin{array}{l}\text { Limited adverse } \\
\text { impacts }\end{array}$ & $\begin{array}{l}\text { (Gonzalez-Estrella et al., } \\
2016,2015 b \text { ) }\end{array}$ \\
\hline Nano- $\mathrm{Ag}^{0}$ & $<100$ & $1500 \mathrm{mg} / \mathrm{L}$ & $\begin{array}{l}\text { Only one } \\
\text { publication }\end{array}$ & $\begin{array}{l}\text { (Gonzalez-Estrella et al., } \\
\text { 2013) }\end{array}$ \\
\hline Nano-Ag & $\sim 20^{\mathrm{a}}$ & $40 \mathrm{mg} / \mathrm{L}$ & $\begin{array}{l}\text { Limited adverse } \\
\text { impacts }\end{array}$ & (Yang et al., 2012a) \\
\hline Nano-Au & $\sim 20^{\mathrm{a}}$ & $0.10 \mathrm{mg} / \mathrm{mL}$ & $\begin{array}{l}\text { Only one } \\
\text { publication }\end{array}$ & (García et al., 2012) \\
\hline Nano- $\mathrm{Mn}_{2} \mathrm{O}_{3}$ & $<100$ & $1500 \mathrm{mg} / \mathrm{L}$ & $\begin{array}{l}\text { Only one } \\
\text { publication }\end{array}$ & $\begin{array}{l}\text { (Gonzalez-Estrella et al., } \\
\text { 2013) }\end{array}$ \\
\hline Nano- $\mathrm{TiO}_{2}$ & 25 & $500 \mathrm{mg} / \mathrm{L}$ & Best performance & (Farghali et al., 2019) \\
\hline
\end{tabular}

a: Approximately.

b. Total suspended solids. 